\title{
Monitorowanie procesów cieplnych spawania
}

\author{
Monitoring of Welding Thermal Processes
}

\section{Streszczenie}

Ocena ciepła wprowadzonego do złącza spawanego, szczególnie na etapie opracowywania technologii spawania, czy monitorowania procesu spawania coraz częściej obejmuje bezstykowe metody pomiaru temperatury za pomocą pirometrów, termografów czy systemów termowizyjnych. Jednak pomiar promieniowania podczerwonego wyemitowanego przez nagrzane ciało związany jest z szeregiem uwarunkowań, których nieznajomość może prowadzić do niewłaściwej oceny wartości temperatury badanego obiektu. Niniejsze opracowanie przybliża niektóre aspekty, związane z monitorowaniem procesów cieplnych towarzyszących łączeniu metali z wykorzystaniem technologii spawalniczych. Przedstawiono również przykład możliwości zastosowania termowizji do rejestracji rozkładu temperatury wzdłuż drutu elektrodowego podczas spawania impulsowego w osłonie gazów ochronnych.

Słowa kluczowe: termowizja, prędkość stapiania elektrod, ciepło wprowadzone

\section{Abstract}

Contactless testing which allows the assessment of the temperature using pyrometer, thermograph and vision systems are used increasingly to evaluate the heat input into weld, especially during the development of welding procedure or monitoring of welding. However, the measurement of infrared radiation emitted by a heated object is dependent on many conditions ignorance of which might lead to the incorrect evaluation of the temperature value. The following work introduces some aspects of thermal processes monitoring which accompany metal joining with the use of welding technologies. The article presents the example of applications of thermovision to register of the temperature distribution at the welding electrode tip during GMAW-P.

Keywords: thermography, melting rate, heat input

\section{Wstęp}

Uzyskanie wysokojakościowych produktów z zastosowaniem technologii spawalniczych przy jednoczesnej maksymalizacji wydajności spawania możliwe jest głównie na drodze zastosowania mechanizacji, automatyzacji lub robotyzacji procesu spawania. Te z kolei wiążą się z kontrolą, monitorowaniem parametrów procesu i ich sterowaniem w czasie rzeczywistym. Pomiar podstawowych parametrów takich jak: natężenie prądu spawania, napięcie łuku, prędkość przemieszczania materiału dodatkowego do jeziorka spawalniczego czy szybkość przesuwu źródła ciepła obecnie nie nastręcza większych problemów. Jednak kontrola i monitorowanie w czasie rzeczywistym podstawowej wielkości jakim jest temperatura w strefie spawania tj.: w spoinie, w strefie wpływu ciepła oraz w stapianych materiałach dodatkowych napotyka na szereg trudności wynikających m.in. z wysokiej temperatury źródeł ciepła oraz dużej dynamiki procesu spawania, ograniczających zastosowanie klasycznych metod pomiaru bezpośredniego (np. za pomocą termoelementów).

Aby dotrzymać reżimów technologicznych $w$ trakcie łączenia materiałów z zastosowaniem spawania łukowego, ilość ciepła wprowadzanego do złącza utrzymywana powinna być w ustalonych granicach tj. aby jej wartość nie była ani zbyt mała, ani nie przekraczała ustalonych poziomów. Zwykle do oceny ciepła wprowadzonego stosuje się pośrednie, zastępcze wielkości takie jak np. energia liniowa spawania. Jednak duże rozbieżności w ocenie tego parametru oraz niewłaściwe jego szacowanie wykazane w szeregu opracowań $[1,2]$ pokazują, że stosowanie tej wielkości nie odzwierciedla rzeczywistego ciepła wprowadzonego do złącza, a tym samym wykorzystanie jej do kontroli procesu oraz jakości gotowego wyrobu może być znacznie ograniczone.

\section{Podstawowe wymagania wobec pomiarów bezstykowych}

Procesy spawalnicze charakteryzują się wysokimi maksymalnymi temperaturami, dużym ich gradientem i zróżnicowaniem, zatem pomiary temperatury obejmują różne strefy w obszarze spawania tj.:

- źródło ciepła - które określane jest przez rozkład temperatury w: płomieniu gazowym, tuku spawalniczym lub plazmie.

Dr inż. Krzysztof Kudła, mgr inż. Krzysztof Makles - Politechnika Częstochowska. 
Temperatura płomienia acetylenowego osiąga wartość bliską 3100 „ spawalniczego łuku elektrycznego - 12 000, natomiast w jądrze plazmy podczas cięcia nawet 30000 . Dlatego pomiary rozkładu temperatury źródeł ciepła pomimo, że są niezbędne do poznania zjawisk zachodzących w przestrzeni międzyelektrodowej, to jednak z uwagi na szereg trudności związanych z samym pomiarem - nie są stosowane w praktyce spawalniczej a jedynie ograniczają się do badań laboratoryjnych.

- jeziorko spawalnicze i topione spoiwo - których temperatura zależy głównie od rodzaju materiału dodatkowego i podstawowego, obejmując pomiary podczas nagrzewania, topienia, wrzenia oraz krystalizacji ciekłego metalu. Szacuje się, że przy spawaniu stali temperatura ciekłej kropli wynosi około $2500{ }^{\circ} \mathrm{C}$, natomiast jeziorka spawalniczego osiąga wartość $2000^{\circ} \mathrm{C}$ [3].

- materiał podstawowy i strefę wpływu ciepła - inspekcja dotyczy rozkładu temperatury na powierzchni spawanych elementów i kontroli cyklu cieplnego w obszarze SWC. Są to najczęściej wykonywane pomiary stosowane w praktyce spawalniczej dlatego, że są niezbędne podczas opracowywania technologii spawania.

Dobór odpowiedniej metody pomiaru dokonuje się ze względu na:

- dostępność aparatury oraz łatwość wykonania pomiaru przy dostatecznej dokładności,

- możliwość pomiaru temperatury na dowolnej długości złącza i w szerokim zakresie temperatury,

- brak ingerencji urządzeń pomiarowych w przebieg procesu, które mogłyby powodować jego zakłócanie.

Do oceny stopnia nagrzania elementów spawanych konstrukcji metalowych często stosowane są kredki indykatorowe. Taki pomiar obarczony jest jednak szeregiem wad m.in.: małą dokładnością i ograniczonym zakresem mierzonych temperatur oraz brakiem możliwości rejestracji temperatury podczas stygnięcia [4]. Metoda ta jest jednak wystarczająca do określania temperatury przy powszechnie stosowanych zabiegach spawalniczych jak np. podczas podgrzewania materiału przed spawaniem.

\section{Zastosowanie termowizji do analizy jakości produkcji}

Promieniowanie elektromagnetyczne w tym podczerwone emitowane jest przez każde ciało o temperaturze wyższej od zera bezwzględnego. Jeżeli temperatura obiektu nie przekracza około $500{ }^{\circ} \mathrm{C}$ to promieniowanie cieplne emitowane jest w zakresie podczerwieni [5]. Powyżej tej temperatury część promieniowania emitowana przez ciało stanowi promieniowanie widzialne [6], dzięki czemu temperaturę nagrzewanego ciała można oszacować na podstawie odbieranych barw (tabl. I).

Główną trudnością przy stosowaniu pomiarów termowizyjnych jest określenie emisyjności badanego obiektu. Wielkość ta zwiera informację o zdolności obiektu do emisji promieniowania cieplnego, która zależy od rodzaju materiału, temperatury nagrzanego elementu, geometrii i stanu jego powierzchni (polerowana, utleniona), częstotliwości widma elektromagnetycznego oraz odległości i kąta obserwacji. Najczęściej wymaga się by wartość współczynnika emisyjności określana była na drodze eksperymentalnej przez pomiar temperatury badanego ciała pokrytego taśmą lub farbą o wysokiej i znanej emisyjności lub przez odniesienie rejestrowanej temperatury za pomocą metod bezstykowych do zmierzonej za pomocą np. ogniwa termoelektrycznego.

W praktyce spawalniczej, z uwagi na występującą dużą zmienność materiałów wykorzystywanych przez wytwórcę konstrukcji - bezstykowe pomiary temperatury obejmują metale różniące się emisyjnością co prowadzi do znacznych błędów w określeniu temperatury badanych obiektów, jeśli nie zastosuje się kalibracji urządzenia pomiarowego. Obecnie produkowane rejestratory wyposażane są w oprogramowanie, które pozwala na podstawie znanego składu chemicznego mierzonego materiału - automatycznie obliczyć emisyjność, ułatwiając tym samym prowadzenie inspekcji konstrukcji spawanej.

Tablica I. Barwa żarzenia w zależności od temperatury Table I. The dependence of the incandescence colour on the temperature

\begin{tabular}{|c|c|c|}
\hline $\begin{array}{c}\text { Zakres } \\
\text { temperatur }\end{array}$ & \multicolumn{2}{|c|}{ Barwa } \\
\hline $550-580^{\circ} \mathrm{C}$ & ciemnobrunatny & \\
\hline $580-650^{\circ} \mathrm{C}$ & brunatnopurpurowy & \\
\hline $650-750^{\circ} \mathrm{C}$ & purpurowy & \\
\hline $750-780^{\circ} \mathrm{C}$ & ciemnokarminowy & \\
\hline $780-800^{\circ} \mathrm{C}$ & karminowy & \\
\hline $800-830^{\circ} \mathrm{C}$ & karminowo-pomarańczowy & \\
\hline $830-880^{\circ} \mathrm{C}$ & ciemnopomarańczowy & \\
\hline $880-1050^{\circ} \mathrm{C}$ & pomarańczowy & \\
\hline $1050-1150^{\circ} \mathrm{C}$ & żółtopomarańczowy & \\
\hline $1150-1250^{\circ} \mathrm{C}$ & żółty & \\
\hline $1250-1350^{\circ} \mathrm{C}$ & żółtobiały \\
\hline
\end{tabular}

Oprócz określenia współczynnika emisyjności kluczowymi elementami przy pomiarach termowizyjnych jest uniknięcie refleksyjności oraz utrzymanie takiej odległości obiektu od rejestratora, aby wyeliminować zakłócenia spowodowane wpływem ośrodka, w którym rozchodzi się promieniowanie. Należy dążyć do pomiaru temperatury elementu z jak najmniejszej odległości oraz tak dobrać częstotliwość rejestracji pomiarów aby uchwycić gwałtowne zmiany temperatury, szczególnie obiektów znajdujących się w ruchu.

Monitorowanie procesów spawalniczych przy użyciu metod wizyjnych pozwala na ocenę poziomu parametrów oraz jakości wyrobu i procesu produkcyjnego. Celem identyfikacji niezgodności występujących w metalach czy ich niejednorodności wykorzystuje się tzw. termografię aktywną, która wykorzystuje analizę rozkładu temperatury na powierzchni elementu, poddawanego działaniu energii zeźródła zewnętrznego [7]. Najczęściej do tego celu wykorzystuje się ogrzewanie obiektu za pomocą lamp halogenowych (rys.1), promieniowania laserowego, bądź też pobudza się strukturę metalu poddanego pomiarom za pomocą przetworników piezoelektrycznych wywołujących drgania

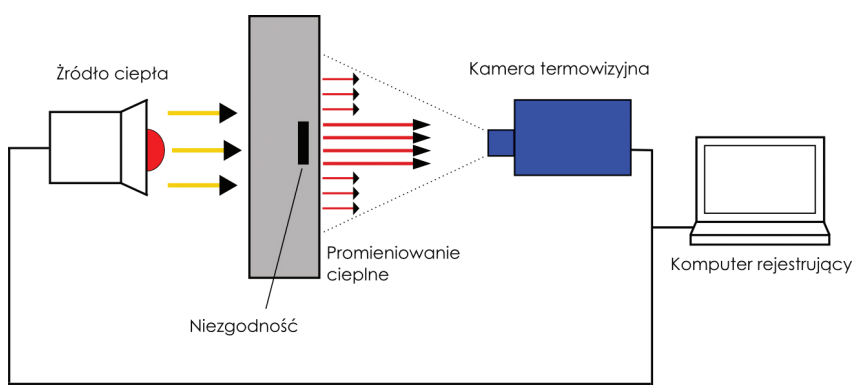

Rys. 1. Detekcja niezgodności materiałowych za pomocą aktywnej termografii

Fig. 1. Detection of material flaws with the use of active thermography 
wewnątrz analizowanego elementu. Zaobserwowane duże różnice emisji promieniowania mogą świadczyć o obecności niezgodności w materiale.

Inną interesującą aplikacją pomiarów termograficznych jest wykorzystanie wysokoczułych kamer termowizyjnych rejestrujących obrazy termiczne $z$ dużymi częstotliwościami (powyżej 1000 klatek/s) do analizy stanu naprężeń w konstrukcjach poddawanych obciążeniom zewnętrznym, wywołującym wewnątrz elementów lokalne przyrosty temperatury. Rozkład temperatury na ich powierzchni odpowiada jakościowo stanowi naprężeń i służy głównie do wykrycia krytycznych obszarów, w których występują spiętrzenia naprężeń.

\section{Monitorowanie procesu nagrzewania i stapiania drutów elektrodowych}

Często wybór technologii spawania nie wynika z najlepszych dostępnych rozwiązań technicznych. Podyktowany jest on innymi czynnikami związanymi m.in. z ograniczaniem kosztów wytwarzania, których wprowadzenie może pogarszać warunki pracy, a nawet obniżać jakość produktu końcowego. Jednym z najprostszych sposobów obniżania kosztów spawania jest wzrost wydajności procesu przez zwiększenie uzysku stapianych materiałów dodatkowych. Dotyczy to szczególnie elektrod charakteryzujących się wysoką rezystywnością, powodującą nagrzewanie drutu elektrodowego, przez przepływający prąd elektryczny.

Według Halmoya [8] szybkość stapiania drutu elektrodowego zależy od temperatury kropli ciekłego metalu oraz efektywnego potencjału stapiania, który zasadniczo jest równy lub mniejszy od pracy wyjścia elektronu. Stwierdzenie to podaje w wątpliwość wpływ rodzaju gazu osłonowego na stapianie elektrody. Ten sam autor obliczył, że oderwane krople są nagrzane tylko nieco powyżej temperatury topnienia, a energia potrzebna do ogrzania i stopienia jednego grama stali wynosi około $1440 \mathrm{~J} \cdot \mathrm{g}^{-1}$. Inne źródła [9] na podstawie pomiarów kalorymetrycznych podają wartość temperatury kropli równą, a nawet wyższą od temperatury wrzenia stali. Jednak próby bezpośredniego pomiaru temperatury były dość niedoskonałe, gdyż albo nie uwzględniały rzeczywistych warunków spawania, albo brały pod uwagę temperaturę wyłącznie na powierzchni kropli.

Wielu spośród badaczy zjawisk stapiania zakłada, że temperatura na końcu elektrody jest równa temperaturze topnienia, a nagrzany przez ciepło łuku metal powyżej jego punktu topnienia jest odrywany i transportowany do materiału podstawowego. Ciepło z końca drutu przewodzone jest do litej części elektrody i płynie do dyszy stykowej o stałej temperaturze (z uwagi na chłodzenie palnika wodą lub powietrzem). Z opisanych powyżej założeń oraz posuwu drutu ze stałą prędkością, rozkład temperatury w wysuniętym odcinku może być opisany przez równanie przepływu ciepła [10]:

gdzie:

$$
\frac{\partial T}{\partial t}+V_{e} \frac{\partial T}{\partial x}=k \frac{\partial^{2} T_{e}}{\partial x^{2}}+\frac{J^{2} R(T)}{c \rho}
$$

$T_{e}=T_{e}(x, t)$ - temperatura w wysuniętym odcinku w odległości $x[m]$ od dyszy stykowej,

$V_{e}\left[m \cdot s^{-1}\right]$ - prędkość posuwu drutu,

$k=\frac{K}{c p}\left[m^{2} \cdot s^{-1}\right]-$ prędkość temperaturowa (współczynnik przenikania temperatury),

$K\left[W \cdot(m \cdot K)^{-1}\right]$ - przewodność cieplna (współczynnik przewodzenia ciepła),

$p\left[k g \cdot m^{3}\right]$ - masa właściwa,

$c\left[J \cdot\left(k g \cdot K^{-1}\right)\right]$ - ciepło właściwe,

$J\left[A \cdot m^{2}\right]$ - gęstość prądu,

$R=R(T)[\Omega \cdot m]-$ rezystywność przy danej temperaturze $T$.
Hirata [10] założył jako stałe: długość łuku i wysuniętego odcinka elektrody oraz wartość prądu spawania. Aby istniało analityczne i nieuwikłane rozwiązanie równania przepływu ciepła pominął również rezystywność niezależną od temperatury $R(T)=R_{0}$. Na podstawie tych założeń otrzymał znajdujący się w quasi-stacjonarnym stanie $\left(\frac{\partial T}{\partial t}=0\right)$ rozkład temperatury
w drucie:

$\mathrm{T}(\mathrm{x})=\left(\mathrm{Tm}-\mathrm{Te}-\frac{l_{e}}{V_{e}} \cdot \frac{J^{2} R_{0}}{c p}\right) \cdot \frac{\exp \left(V_{e} \cdot \frac{x}{k}\right)-1}{\exp \left(V_{e} \cdot \frac{l_{e}}{k}\right)-1}+\frac{J^{2} R_{0}}{c p} \cdot \frac{x}{V_{e}}+\mathrm{T}_{0}$

gdzie:

$T_{0}=[K]$ - temperatura przy dyszy stykowej $(x=0 m)$,

$V_{e}=\left[m \cdot s^{-1}\right]$ - prędkość posuwu elektrody.

Zbyt duże uproszczenia prowadzić jednak mogą do znacznych błędów, gdyż zarówno współczynnik przenikania temperatury zmienia się $w$ znacznym zakresie, a oporność stali rośnie z temperaturą o rząd wielkości sprawiając, że powyższe założenia tracą sens. Niektóre badania [11,12] pokazują, że temperatura dyszy stykowej w wyniku działania łuku wzrasta nieliniowo z czasem spawania nawet do około $800{ }^{\circ} \mathrm{C}$. Dlatego w obliczeniach powinny być uwzględnione rzeczywiste zmiany temperatury.

Obliczenia oraz modelowanie nagrzewania i stapiania drutu narażone są na szereg ograniczeń i trudności wynikających z nie do końca rozpoznanych procesów zachodzących w łuku oraz znacznej liczby czynników wpływających na stapianie elektrody. Dlatego badania doświadczalne obejmujące stapianie materiałów dodatkowych, należą do podstawowych prowadzonych w procesach spawania łukowego.

Jedną z metod badania procesu topienia i przenoszenia ciekłego metalu elektrody może być zastosowanie termografii oraz szybkiej fotografii (rys. 2).
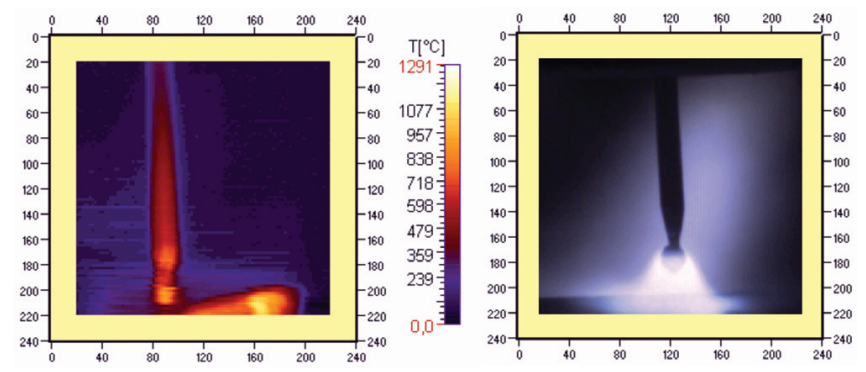

Rys. 2. Zarejestrowane obrazy stanu przestrzeni międzyelektrodowej z zastosowaniem termografii i szybkiej fotografii w trakcie spawania MAG Puls

Fig. 2. The registered images of interelectrode space with the use of thermography and high - speed fotography during GMAW-P

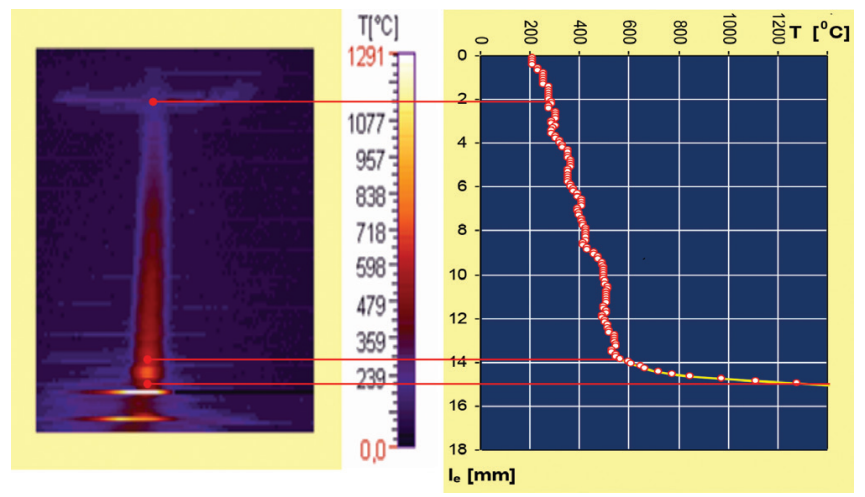

Rys. 3. Zmiana temperatury wzdłuż wysuniętego odcinka drutu w trakcie spawania w osłonie gazów ochronnych metodą MIG/MAG Fig. 3. Change of temperature along the wire stickout during GMAW

Problemem występującym w trakcie pomiaru temperatury jest mały rozmiar badanego obiektu (drut elektrodowy o średnicy około $1 \mathrm{~mm}$ ) i jego znaczna prędkość dochodzącą do $20 \mathrm{~m} / \mathrm{min}$. Dodatkowo promieniowanie i unoszenie ciepła 
z łuku elektrycznego może wpływać na wynik pomiaru. W przeprowadzonych badaniach eksperymentalnych, aby ograniczyć wpływ wymienionych uwarunkowań zastosowano dynamiczny pomiar temperatury wzdłuż drutu elektrodowego (czas pomiaru ok. $2 \mathrm{~ms}$ ) oraz wykorzystano wysokoczułą optykę termografu, pozwalając zmierzyć temperaturę drutu z odległości ok. $30 \mathrm{~mm}$.

$\mathrm{Na}$ rysunku 3 przedstawiono zarejestrowany obraz termiczny i zmianę temperatury wzdłuż drutu elektrodowego wywołaną oporowym nagrzewaniem i oddziaływaniem ciepła

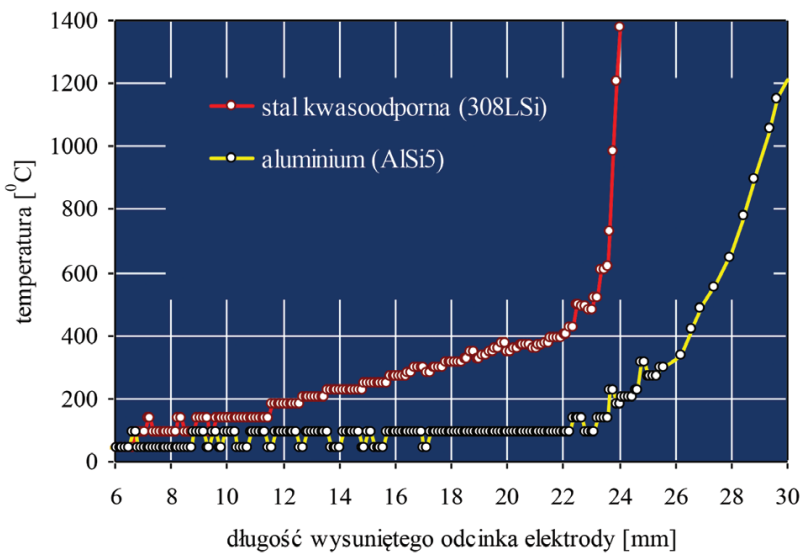

Rys. 4. Zmiana temperatury wzdłuż wysuniętego odcinka drutu elektrodowego podczas spawania stali wysokostopowych i stopów aluminium

Fig. 4. Change of temperature at the wire stick-out during stainlees steel and aluminium alloys welding łuku. Temperatura wzdłuż wysuniętego odcinka rośnie liniowo i w pewnej odległości od łuku gwałtownie wzrasta. Charakter zmian temperatury zależy od rodzaju materiału spoiwa, średnicy i długości elektrody przewodzącej prąd oraz od prędkości posuwu drutu i wartości prądu spawania. Uzyskane wyniki (rys. 4) pokazują, że zwiększanie prędkości stapiania drutu elektrodowego przez podwyższanie długości wysuniętego odcinka drutu elektrodowego ma sens jedynie w przypadku materiałów o dużej oporności.

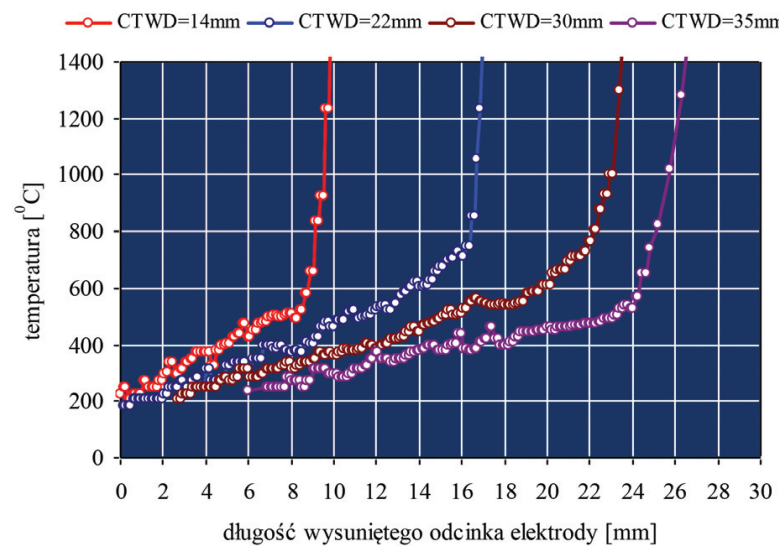

Rys. 5. Wpływ zmian odległości dyszy stykowej od materiału spawanego (CTWD - Contact Tip to Workpiece Distance) na temperaturę wzdłuż elektrody w procesie MAG Puls $\left(316 \mathrm{LSi} ; \mathrm{d}_{\mathrm{e}}=1,2 \mathrm{~mm} ; \mathrm{V}_{\mathrm{e}}=2,8 \mathrm{~m} / \mathrm{min}\right.$; $\mathrm{I}_{\mathrm{b}}=50 \mathrm{~A} ; \mathrm{t}_{\mathrm{i}}=1,9 \mathrm{~ms} ; \mathrm{f}_{\mathrm{i}}=56 \mathrm{~Hz} ; \mathrm{U}_{\mathrm{i}}=33,5 \mathrm{~V}$ )

Fig. 5. Influence of changes of contact tip to workpiece distance on temperature at the wire stick-out during GMAW-P (316LSi; $d_{e}=1,2$ $\mathrm{mm} ; \mathrm{V}_{\mathrm{e}}=2,8 \mathrm{~m} / \mathrm{min} ; \mathrm{I}_{\mathrm{b}}=50 \mathrm{~A} ; \mathrm{t}_{\mathrm{i}}=1,9 \mathrm{~ms} ; \mathrm{f}_{\mathrm{i}}=56 \mathrm{~Hz} ; \mathrm{U}_{\mathrm{i}}=33,5 \mathrm{~V}$ )

\section{Podsumowanie}

Przeprowadzone badania oraz analizy pozwalają na wysunięcie poniższych wniosków.

Z dużym prawdopodobieństwem można przyjąć, że temperatura końca drutu jest niezależna od prądu płynącego przez elektrodę. Jednak z uwagi na ograniczony zakres pomiarowy termografu należy przeprowadzić szczegółową analizę tego zagadnienia. Ponieważ w przypadku, gdy drut elektrodowy jest anodą podtrzymującą łuk należy uwzględnić związek między plamką anodową i prądem.

Dla metali o małej oporności cieplnej i elektrycznej takich jak aluminium temperatura wzdłuż wystającego odcinka zmienia się niewiele, dopiero w odległości około 4-6mm od łuku zaczyna gwałtownie wzrastać. Nagrzewanie elektrody przez łuk odnosi się do odcinka, który stanowi około 10\% długości wysuniętej elektrody z dyszy prądowej.

Podczas spawania z zastosowaniem materiału spoiwa o dużej oporności (stal austenityczna) przebieg zmian temperatury wzdłuż wysuniętego odcinka elektrody różni się zasadniczo od metali o dużym przewodnictwie cieplnym. Gradient temperatury w elektrodzie spowodowany nagrzewaniem oporowym jest wyższy i wynosi średnio. W odległości około 1-2mm od łuku temperatura gwałtownie wzrasta, co stanowi średnio $5 \%$ długości elektrody.

Pomiary termowizyjne wymagają od prowadzącego badania dużego doświadczenia podczas ustalania parametrów pomiaru a następnie oceny uzyskanych wyników. Pełne wykorzystanie aplikacji termowizyjnych jest możliwa przy świadomym stosowaniu aparatury pomiarowej. llość czynników wpływająca na badanie sprawia, że pomiary termowizyjne należą do badań złożonych. Termowizyjny pomiar temperatury pozwala na poznanie rzeczywistego stopnia nagrzania materiałów, co umożliwia właściwą ocenę prowadzonego procesu spawania.

\section{Literatura}

[1] Kudła K., Wojsyk K.: Normowana energia liniowa a ilość ciepła wprowadzonego podczas spawania. Przegląd Spawalnictwa 12/2010, s. 21-25.

[2] Wojsyk K.: Badanie metodą termograficzną energii liniowej spawania i napawania. Przegląd Spawalnictwa, 8/2007, s. 34-38.

[3] Pietras A., Węglowska A., Kowieski Sz., Miara D.: Nowoczesne systemy monitorowania procesu zgrzewania tarciowego metodą FSW. Biuletyn Instytutu Spawalnictwa 5/2012, s. 160-167.

[4] Havalda A.: Procesy cieplne przy spawaniu elektrycznym. WNT. Warszawa 1963.

[5] Minkina W.: Pomiary termowizyjne - przyrządy i metody. Wydawnictwo Politechniki Częstochowskiej, Częstochowa 2004.

[6] Michalski L., Eckersdorf K., McGhee.: Temperature Measurement. John Wiley \& Sons, Chichester. International Journal of Adaptive Control and Signal Processing Vol. 6, Issue 5, pp. 515-516, September 1992.
[7] Pawlak S., Różański M., Stano S., Muzia G.: Termografia aktywna jako nowa metoda badań nieniszczących połączeń zakładkowych spawanych laserowo. Przegląd Spawalnictwa 3/2014, s. 4-10.

[8] Halmoy E.: Wire melting rate, droplet temperature, and effective anode melting potential. paper 29, London, May, 1979, s. 49-57.

[9] Jelmorini G., Tichelaar G.W., Van den Heuvel G.J.P.M: Droplet temperature measurements in arc welding. IIW Doc.212-411-77, 1977

[10] Hirata Y.: Physic of welding (III) - Melting rate and temerature distribution of elektrode wire. Welding International, September 1995, nr 5, s. 348-351.

[11] Dörhöfer F., Pomaska H.U.: Welche Anforderungen muß eine MetallÁktivgassschweißanlage erfüllen. Schweißen und Schneiden, 1978, nr 12, s. 491-496.

[12] Pomaska H.U.: MAG Welding „Not a Sealed Book”. Linde. Industrial Gases, Munich, 1989. 


\section{Podsumowanie}

Rok 2015 dla branży gazowniczej będzie przełomowy. Jest to rok rozpoczęcia największych inwestycji na polskim rynku, które niosą za sobą wysokie wymagania odnośnie jakości, jak i technologii wykonywania złączy spawanych. Mowa jest o wymaganej mechanizacji procesu podczas wykonywania połączeń spawanych. W polskich firmach zajmujących się realizacją inwestycji gazowych, proces zmiany sposobu wykonywania złączy spawanych trwa już od kilku lat. W celu spełnienia wymagań stawianych przez głównego inwestora na polskim rynku GAZ SYSTEM. Autorzy obrali za cel niniejszej pracy porównanie właściwości i efektów spawania ręcznego i zmechanizowanego. Porównania dokonano na przykładzie grupy spawalniczej wykonującej złącza spawane na rurze DN700x11,0 mm ze stali L485MB. Porównano dwie grupy wykonujące złącza spawane, tą samą metodą spawania, jednak różnymi sposobami. W powyższej pracy porównano metodę ręczną ze zmechanizowaną na podstawie: parametrów spawania oraz czasu pracy. Na koniec zobrazowano pracochłonność wykonania 1000 spoin przez obie te grupy. Zestawienie parametrów spawania ujawniło o wiele wyższą prędkość spawania zmechanizowanego, przy porównywalnych wartości parametrów spawania oraz utrzymaniu odpowiedniego poziomu ilości ciepłą wprowadzanego do złącza. Na przykładzie 1000 spoin pokazano jaki wpływ ma mechanizacja procesu spawania na czas realizacji zadania. Mechanizacja na przykładzie czołówki spawalniczej nie zmienia systemu pracy całej grupy, zmiana dotyczy tylko spawania i czynności związanych ze spawaniem, reszta pozostaje taka jak przy spawaniu ręcznym. Jednak czy to w przypadku spawania ręcznego czy zmechanizowanego to człowiek nadal jest najważniejszym ogniwem i to on ma największy wpływ na jakość, efektywność oraz wydajności procesu wykonywania złączy spawanych.

\section{Literatura}

[1] T. Chmielewski, M. Węglowski, K. Kudła "Spawanie w pozycji PF metodą MMA z wykorzystaniem nowej funkcji UP w zasilaczach inwertorowych zbudowanych w technice MICOR" Przegląd Spawalnictwa, Vol. 86, Nr. 9, s. 45-49, 2014.

[2] M. Węglowski, T. Chmielewski, K. Kudła "Ocena wydajności spawania niskoenergetycznego procesu SpeedRoot w pozycji PG "Przegląd Spawalnictwa, Vol. 83, Nr. 12, s. 26-30, 2011.

[3] B. Pawłowski, J. Krawczyk, P. Bała, S. Parzych, M. Paćko „Jakość złączy spawanych rurociągu wody chłodzącej wykonanego ze stali austenitycznej X6CrNiTi18-10" Przegląd Spawalnictwa, Vol. 82, Nr. 4, s. 4-7, 2010.

[4] R. Krawczyk, J. Plewniak, K. Sujewicz "Spawanie metodą MAG grubościennych rurociągów energetycznych ze stali 13HMF - optymalizacja warunków procesu" Przegląd Spawalnictwa, Vol. 78, Nr. 7-10, 2006.
[5] K. Y. Lee, K. Sadurski „Budowa rurociągów przesyłowych oraz możliwości zastosowanianowych kryteriów oceny jakości spoin obwodowych" Przegląd Spawalnictwa, Vol. 81, Nr. 6, s. 6-9, 2009.

[6] T. Chmielewski „Projektowanie procesów technologicznych - Spawalnictwo" Oficyna Wydawnicza Politechniki Warszawskiej, Warszawa, 2013.

[7] T Chmielewski, M Węglowski „Analiza rynku spawalniczego w Polsce pod względem sprzedaży urządzeń oraz materiałów spawalniczych" Przegląd Spawalnictwa vol. 82, nr 6, s. 28-31, 2010.

[7] T. Sałaciński „SPC statystyczne sterowanie procesami produkcji”, Oficyna Wydawnicza Politechniki Warszawskiej, Warszawa, 2009.

[8] T. Sałaciński, W. Sosnowski "System nadzorowania jakości procesów spawalniczych zgodny z wymaganiami ISO 3834 w oparciu o standardy ISO 9001-część 1", Przegląd Spawalnictwa, Vol. 87, nr 4, s. 10-13, 2015. 


\section{Niezawodne rozwiązania FANUC na potrzeby małych i średnich producentów w Polsce}

Zrobotyzowane stanowiska spawalnicze stały się już znakiem rozpoznawczym branży motoryzacyjnej. Jednak ciągły rozwój tej technologii oraz szeroki dostęp do finansowania jej zakupu powoduje, że staje się ona coraz bardziej atrakcyjnym rozwiązaniem dla małych i średnich firm, poszukujących skutecznych sposobów na rozwój własnej działalności.

FANUC, pionier technologii CNC oraz światowy lider $w$ produkcji innowacyjnych rozwiązań z zakresu automatyki przemysłowej i robotyki, może pochwalić się największą spośród wszystkich dostawców liczbą robotów przemysłowych zainstalowanych na świecie w różnorodnych gałęziach przemysłu. Spowodowane jest to przede wszystkim niemającą sobie równych niezawodnością produktów spod znaku japońskiego giganta. Od prawie czterdziestu lat zakłady produkcyjne na całym świecie wykorzystują najnowocześniejsze rozwiązania FANUC, by móc $w$ pełni zaspokoić potrzeby swojej produkcji. Tajemnicą sukcesu koncernu jest przede wszystkim filozofia działania FANUC, która nie zmieniła się od początku istnienia firmy i dotyczy ciągłego dążenia do doskonałości, także $w$ relacjach z klientami. Najważniejszy jest zawsze klient, a oferowane mu rozwiązanie ma być nie tylko najlepsze, ale zawsze dokładnie dopasowane do indywidualnych potrzeb produkcji.

\section{Wszystko dla niezawodności}

Takie podejście japońskiego producenta powoduje, że zanim maszyna znajdzie się $w$ zakładzie klienta, musi wcześniej spełnić szereg wyśrubowanych kryteriów. O tym, że takie testy wypadają znakomicie może świadczyć fakt, że w swoich zakładach produkcyjnych w Japonii, FANUC używa 2000 własnych robotów do produkcji nowych urządzeń. Użyteczność tych maszyn, a w związku z tym ich popularność na świecie wiąże się z ogromnym naciskiem, jaki FANUC kładzie na ciągłe wsłuchiwanie się w potrzeby użytkowników. To także dzięki ich uwagom i oczekiwaniom każde nowe rozwiązanie staje się coraz lepsze. Efektem ciągłego myślenia o zaspokajaniu potrzeb klienta jest również niedościgniona niezawodność robotów FANUC, oszacowana metodą Six Sigma, na poziomie 99,99\%. Takie wskaźniki powodują, że roboty japońskiej marki znajdują szerokie zastosowanie w najbardziej wymagających branżach, w których obowiązują najsurowsze normy w tym

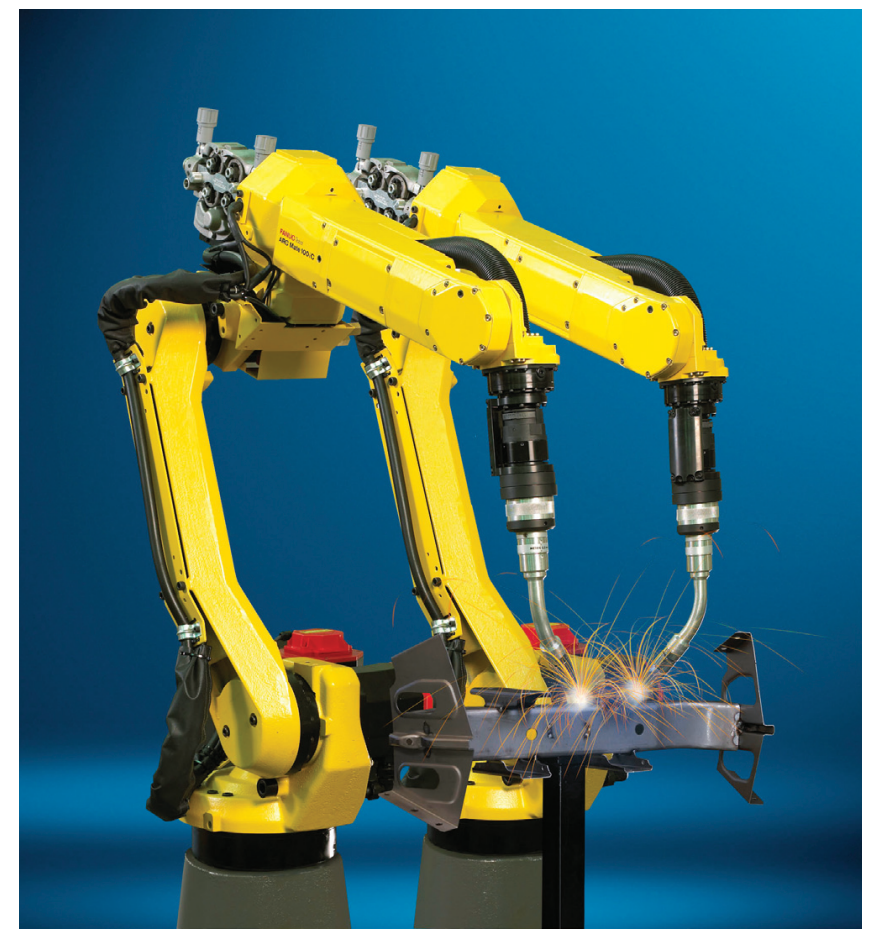

względzie. Do takich branż zalicza się przemysł motoryzacyjny, będący obecnie najbardziej zrobotyzowanym sektorem przemysłu, w którym według najnowszych statystyk Międzynarodowej Federacji Robotyki (IFR) pracuje 39\% wszystkich robotów zainstalowanych w światowym przemyśle.

\section{Elastyczna konfiguracja robotów \\ dedykowanych do procesów spawania}

Różnorodność firm produkcyjnych działających w branży motoryzacyjnej powoduje, że istnieje niezliczony szereg wymogów w zakresie osprzętu spawalniczego, jaki jest wykorzystywany w danym zakładzie. W celu unifikacji i uproszczenia procesów w nim występujących poszczególni producenci zdecydowali się przyjąć pewne standardy wykorzystywanych urządzeń spawalniczych. To oznacza, że każdy z producentów może określić zupełnie inne wymogi zarówno, co do rodzaju źródła spawalniczego, jak i jego osprzętu. Takie podejście wymaga od firm takich jak FANUC dużej elastyczności w zakresie możliwości konfigurowania robotów dedykowanych procesom spawania. By w pełni sprostać potrzebom różnych producentów, roboty FANUC posiadają szereg opcji specjalnie dedykowanych dla praktycznie 
każdego producenta spawarek, niezależnie od tego czy będzie to FRONIUS, LINCOLN ELECTRIC, KEMPI, SKS czy inny, w zależności od indywidualnych preferencji klienta.

Rozwiązania przyjęte przez FANUC powodują, że to $\mathrm{w}$ większości przypadków robot jest odpowiedzialny za sterowanie wszystkimi parametrami spawania a możliwość ich ustawienia dostępna jest na panelu sterowniczym robota. W tym przypadku to robot jest nadrzędny $w$ stosunku to urządzenia spawalniczego. Takie podejście powoduje, że za pośrednictwem panelu robota zadaje się konkretne parametry spawania a następnie płynnie można nimi sterować, w zależności od wymogów technologii spawania. Niejako w odpowiedzi, spawarka przekazuje dane o procesie do robota, który jest w stanie zareagować w czasie rzeczywistym. W ten sposób odbywa się komunikacja obu urządzeń i nie ma tu znaczenia fakt, że robot i urządzenie spawalnicze są różnych marek. Najważniejsza jest tu możliwość szybkiej komunikacji, która dla przykładu, pomiędzy robotem FANUC a urządzeniem spawalniczym marki LINCOLN ELECTRIC, może być nawet dziesięciokrotnie szybsza od konkurencyjnych rozwiązań. Dzięki temu proces spawania adaptacyjnego, gdzie wymagana jest bardzo duża szybkość wymiany informacji, może być znacząco szybszy.

Wysoka elastyczność robotów FANUC w zakresie doboru urządzenia spawalniczego powoduje, że jest to bardzo atrakcyjne rozwiązanie dla polskich producentów, poszukujących sposobów na poprawę swojej konkurencyjności i szybszy rozwój własnych firm. Szeroka dostępność najnowszej technologii od lat wykorzystywanej na świecie oraz możliwości finansowania jej zakupu powodują, że dziś nawet najmniejsze zakłady w Polsce są w stanie skutecznie współzawodniczyć z zagranicznymi firmami nie tylko kosztami produkcji, ale przede wszystkim jakością, wydajnością i przewidywalnością.

\section{Szybki zwrot z inwestycji}

Oczywiście zakup zrobotyzowanego stanowiska spawalniczego wymaga nie tylko środków finansowych, ale przede wszystkim pogłębionej analizy opłacalności takiego wydatku. Wyniki takich analiz będą się różnić w zależności od bardzo wielu czynników, niemniej dane dotyczące wdrożeń dokonanych na przestrzeni ostatnich lat są bardzo zachęcające. Średnio wskaźnik dotyczący zwrotu z inwestycji (ROI) kształtuje się na poziomie 24-36 miesięcy, choć zdarzają się przypadki, gdzie czas ten spada do jedynie osiemnastu miesięcy. Jakkolwiek wskaźnik ten nie byłby istotny, to bardzo często nie jest on najważniejszym parametrem branym pod uwagę przy ocenie opłacalności zakupu zrobotyzowanego stanowiskaspawalniczego. Dziśnajczęstsząprzyczyną wymienianą przez producentów zarówno małych, jak i średnich, jest przede wszystkim brak wykwalifikowanej kadry oraz duża zmienność produkcji. Taka sytuacja powoduje, że nawet najmniejsi producenci rozważają zakup prostych aplikacji spawalniczych. Wiąże się to $z$ wydatkiem rzędu 50 tys. euro netto $\mathrm{i}$ jest to często najlepsza inwestycja mniejszego producenta.

\section{Zapraszamy}

na poznańskie targi MACH - TOOL w czerwcu 2015

Dla wszystkich zainteresowanych producentów z sektora małych i średnich przedsiębiorstw, chcących się dynamicznie rozwijać i poszukujących najlepszych rozwiązań poprawiających jakość i wydajność produkcji, a w efekcie konkurencyjność zakładu na szerszym rynku, FANUC przygotowuje prezentacje najnowszych rozwiązań stworzonych z myślą o zaspokojeniu aktualnych potrzeb producentów. Najbliższa wystawa innowacji FANUC odbędzie się podczas poznańskich targów MACH-TOOL w czerwcu br. Serdecznie zapraszamy do odwiedzenia stoiska FANUC w salonie WELDING.
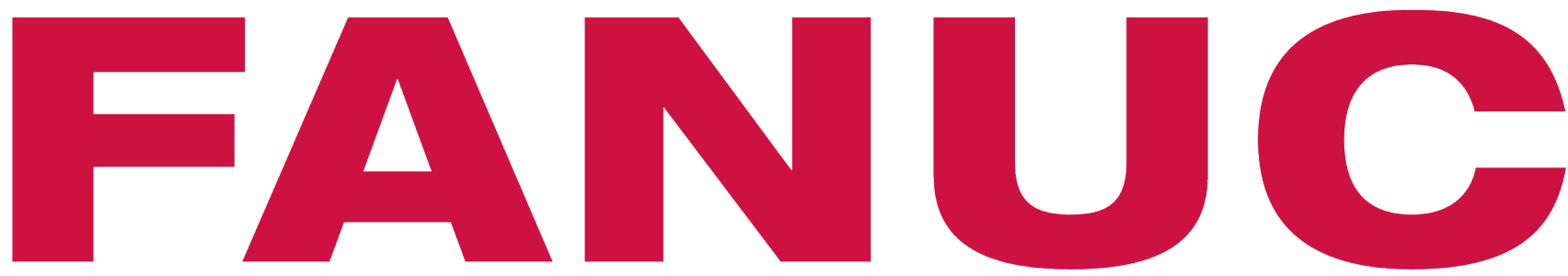


\section{ENERGODIAGNOSTYKA}

\section{BADANIA NIENISZCZĄCE}

$\Omega$ BADANIA METODĄ MAGNETYCZNEJ PAMIĘCI METALU (MPM)

ح BADANIA ULTRADŹWIĘKOWE (UT), W TYM TECHNIKAMI:

- PHASED ARRAY (PA)

- TOFD

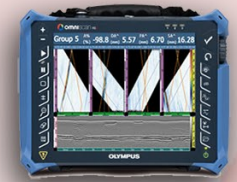

$\Omega$ BADANIA ULTRADŹWIĘKOWE ELEMENTÓW O GRUBOŚCI 2-8 MM

$\Omega$ ULTRADŹWIĘKOWE POMIARY GRUBOŚCI (UTT)

$\Omega$ BADANIA PENETRACYJNE (PT)

$\Omega$ BADANIA PRĄDAMI WIROWYMI (ET)

$\Omega$ BADANIA WIZUALNE (VT)

$\Omega$ BADANIA MAGNETYCZNO - PROSZKOWE (MT)
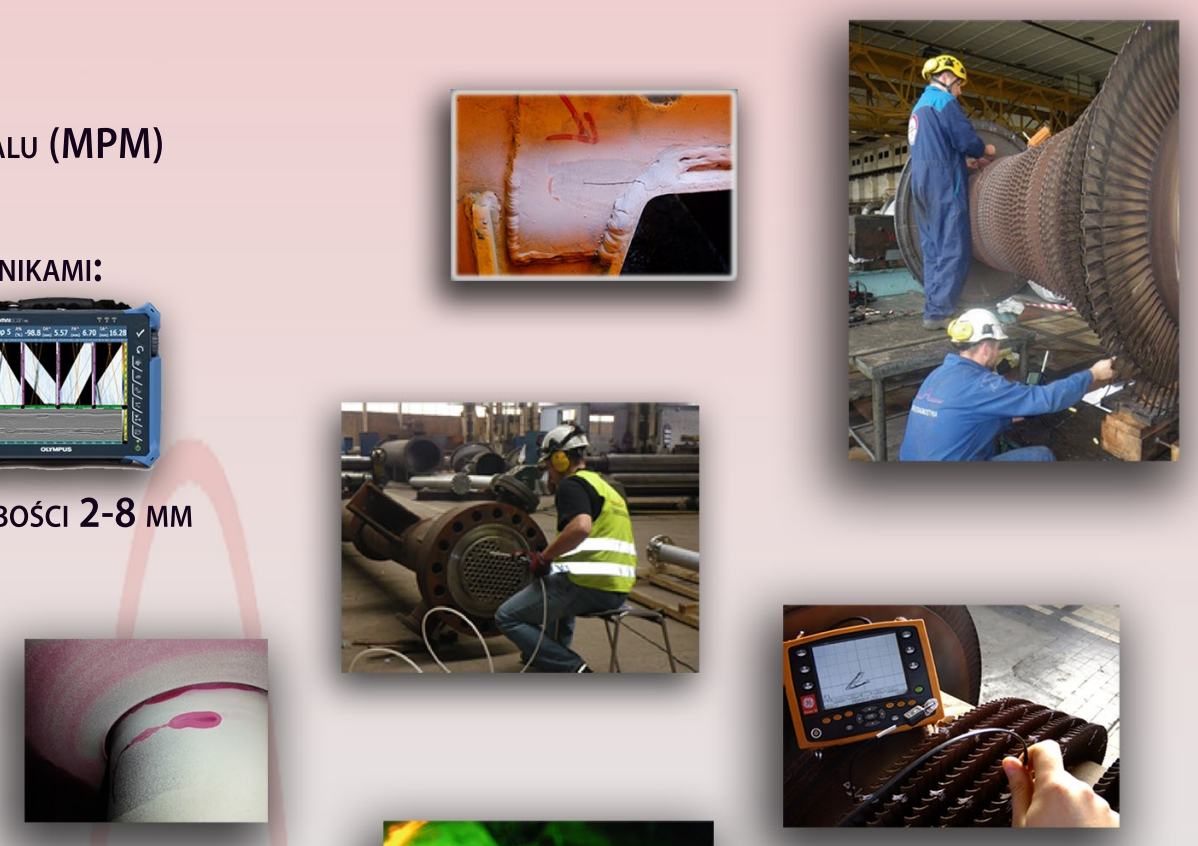

$\Omega$ BADANIA METALOGRAFICZNE (REPLIKI METALOGRAFICZNE, METALOGRAFIA LABORATORYJNA)

$\Omega$ PomiaRY TWARDOŚCI (HB, HV, HRC)

$\Omega$ BADANIA URZĄDZEN WYMIANY CIEPLA

$\Omega$ BADANIA RUROCIĄGÓW IZOLOWANYCH I PODZIEMNYCH BEZ ZDEJMOWANIA IZOLACJI METODA GWT

$\Omega$ MAPOWANIE POWIERZCHNI - RUROCIAQGI, ZBIORNIKI POD KĄTEM UBYTKÓW I USZKODZEŃ
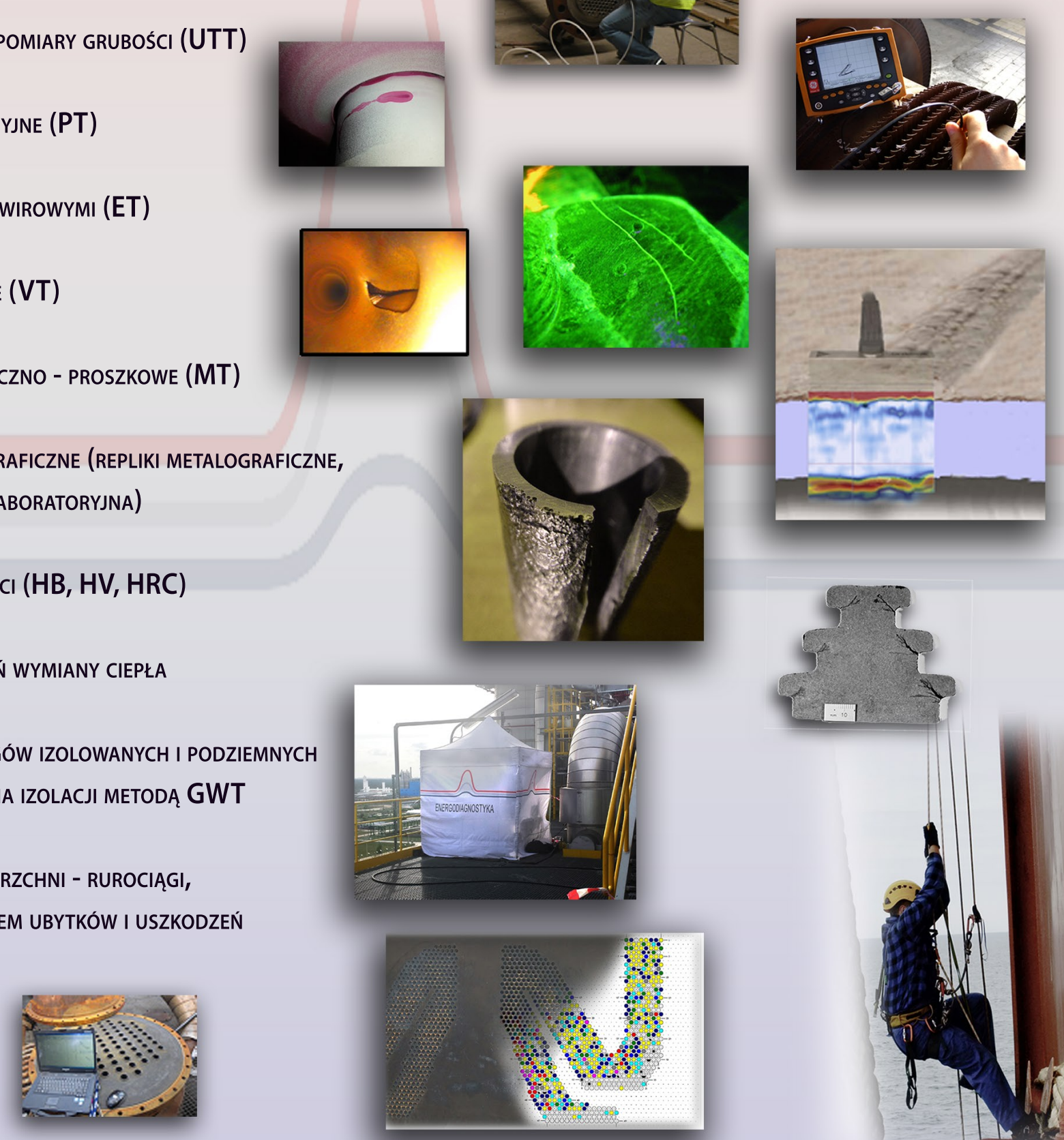


\section{ENERGODIAGNOSTYKA}

\section{OCENA STANU TECHNICZNEGO}

$\Omega$ KOMPLEKSOWE OCENY STANU TECHNICZNEGO KONSTRUKCJI WYKONYWANE W OPARCIU O SZEREG BADAŃ NISZCZACYCH, NIENISZCZACYCH, POMIARÓW, ANALIZ ORAZ OBLICZEŃ INŻYNIERSKICH
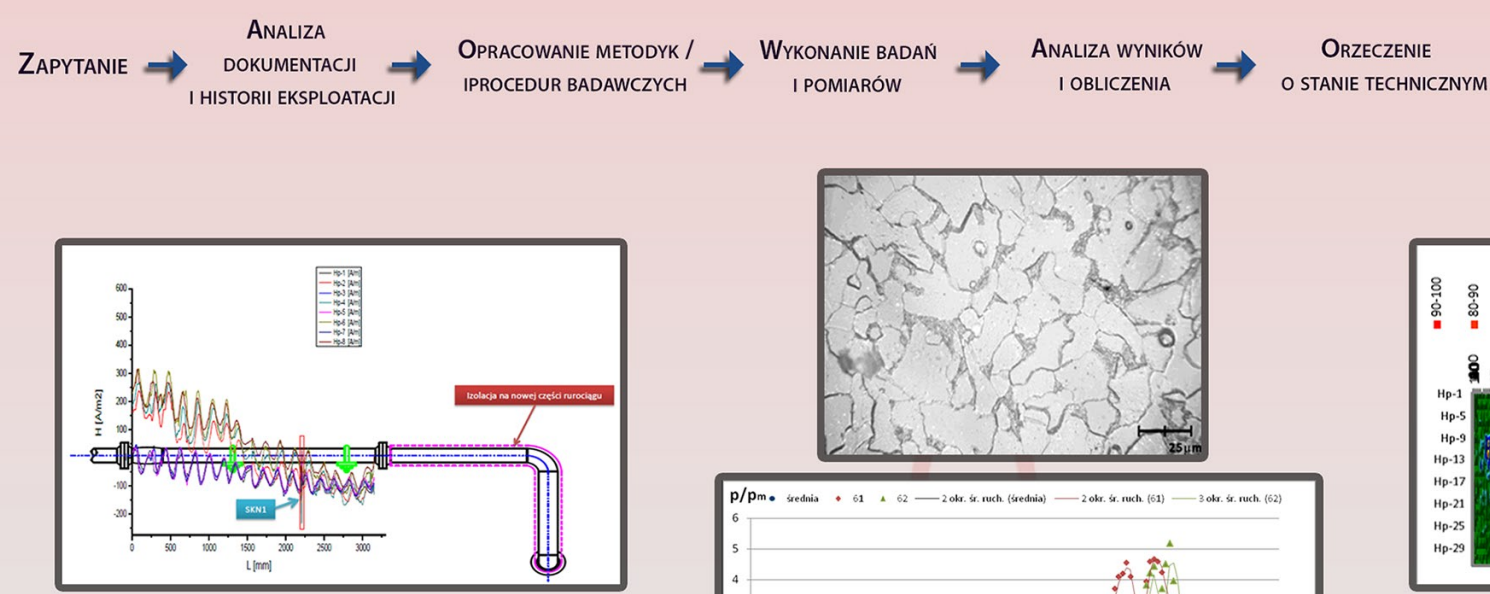

ZaLeCENIA /

PROGNOZA BEZPIECZNEJ EKSPLOATACJ/ OPRACOWANIE DALSZEGo PLANU BADAN
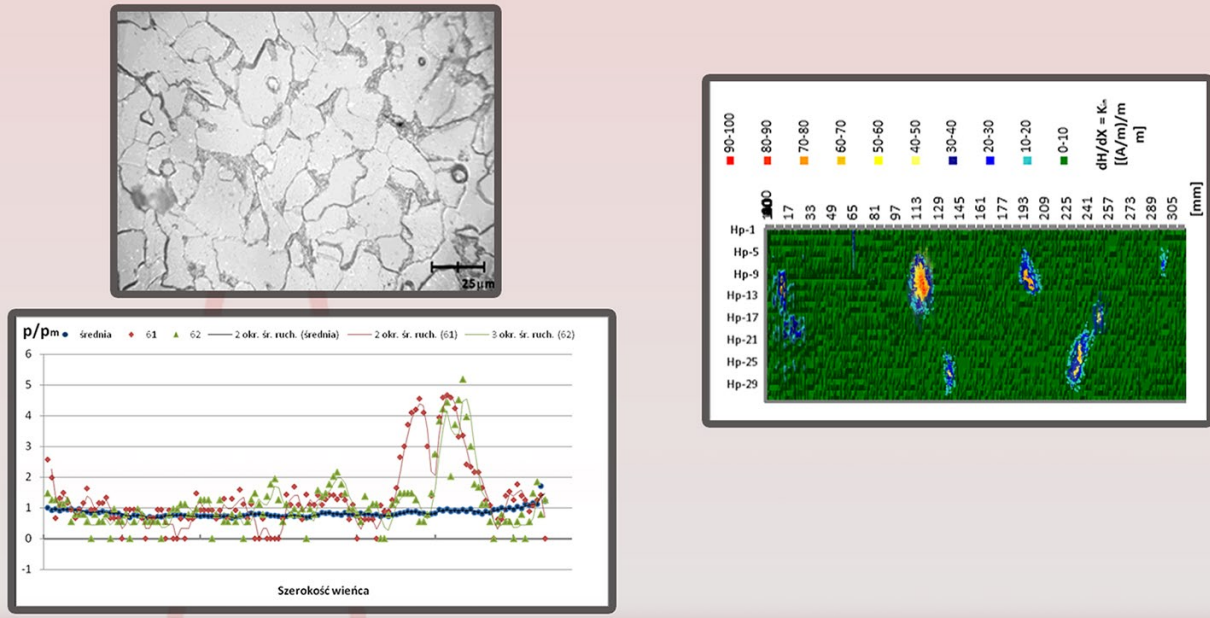

\section{SPRZEDAŻ I SERWIS URZĄDZEŃ} DO METODY MPM

\section{SZKOLENIA I DORADZTWO \\ W ZAKRESIE METODY MPM}

$\Omega$ SPRZEDAŻ PRZYRZĄDÓW POMIAROWYCH I URZĄDZEN SKANUJĄCYCH TSC (TESTER of StRESS Concentration) WRaZ Z CZUJNIKAMI, PRZEZNACZONYMI DO DIAGNOSTYKI TECHNICZNEJ OBIEKTÓW ZA POMOCA METODY Magnetrcznej Pamięci Metalu
$\Omega$ SZKOLENIA PERSONELU W ZAKRESIE METODY MAGNETYCZNEJ PAMIĘCI METALU ZGODNIE Z NORMA EN 9712

$\Omega$ KURSY WDROŻENIOWE

$\Omega$ SERWIS PRZYRZĄDÓW POMIAROWYCH TSC ORAZ CZUJNIKÓW DO BADAŃ METODA MPM

$\Omega$ SPECJALISTYCZNE OPROGRAMOWANIE DO PRZETWARZANIA I ANALIZY DANYCH POMIAROWYCH (MMSYSTEM, MMMLIFETIME)

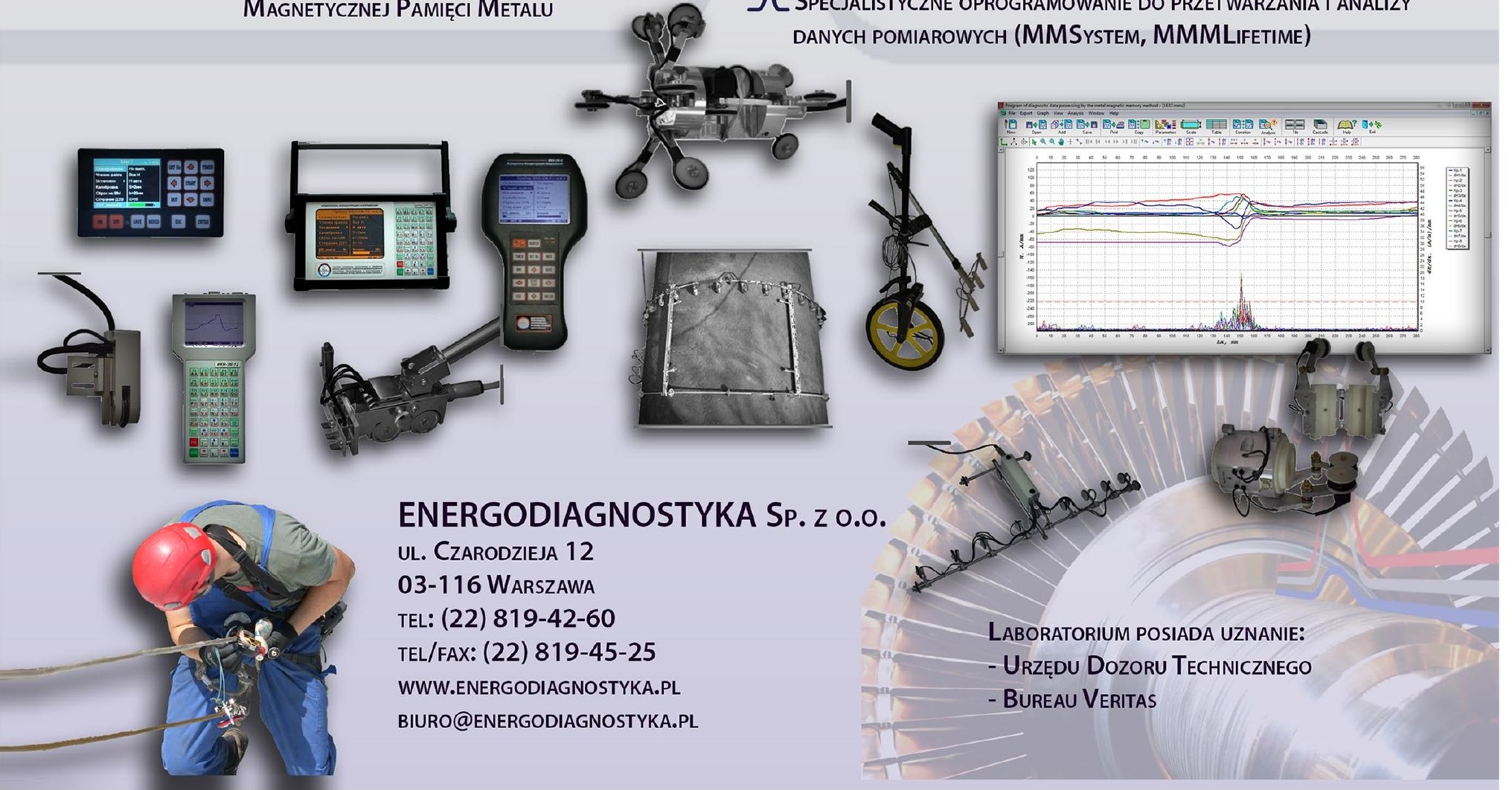




\section{Uroczyste obchody jubileuszu 70-lecia działalności Instytutu Spawalnictwa}
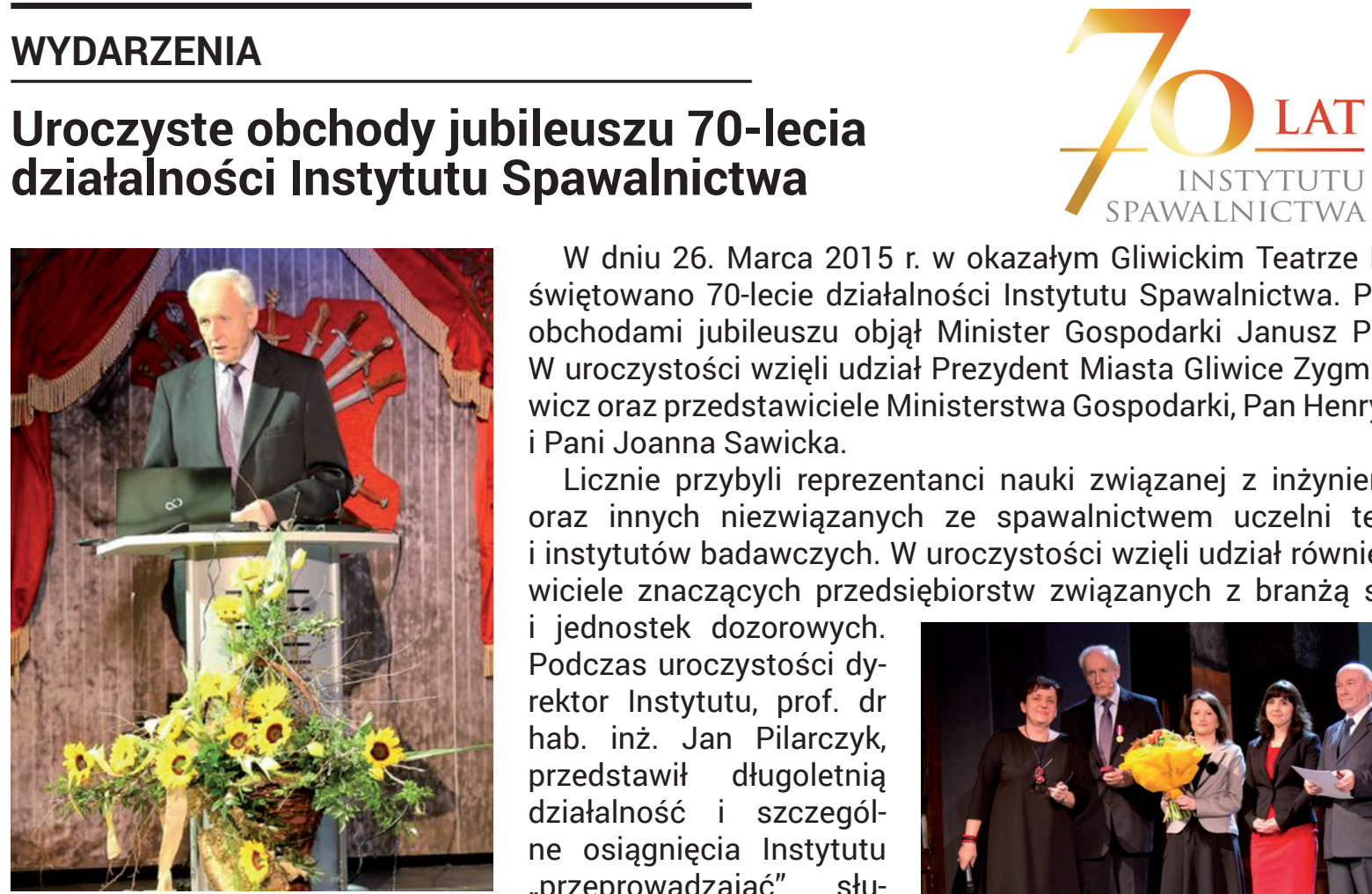

W dniu 26. Marca 2015 r. w okazałym Gliwickim Teatrze Muzycznym świętowano 70-lecie działalności Instytutu Spawalnictwa. Patronat nad obchodami jubileuszu objął Minister Gospodarki Janusz Piechociński. W uroczystości wzięli udział Prezydent Miasta Gliwice Zygmunt Frankiewicz oraz przedstawiciele Ministerstwa Gospodarki, Pan Henryk Nastalski i Pani Joanna Sawicka.

Licznie przybyli reprezentanci nauki związanej z inżynierią spajania oraz innych niezwiązanych ze spawalnictwem uczelni technicznych i instytutów badawczych. W uroczystości wzięli udział również przedstawiciele znaczących przedsiębiorstw związanych z branżą spawalniczą i jednostek dozorowych. Podczas uroczystości dyrektor Instytutu, prof. dr hab. inż. Jan Pilarczyk, przedstawił długoletnią działalność i szczególne osiągnięcia Instytutu „przeprowadzająć" słuchaczy przez kolejne dekady bogatej i często trudnej historii powstania i rozwoju Instytutu. Prof. Pilarczyk wiele uwagi poświęcił ludziom, którzy przez wiele lat tworzyli Instytut i ciężko z oddaniem pracowali na jego pozycję w Polsce i za granicą.

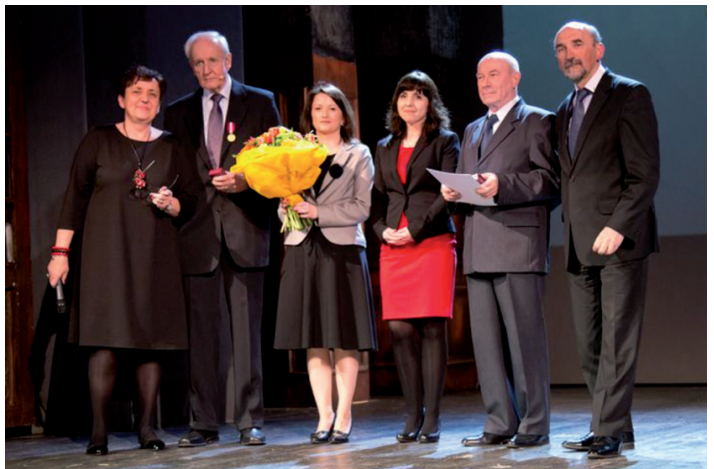

Wiele ciekawych i nieznanych szerzej faktów z historii Instytutu w której osobiste i rodzinne historie pracow-

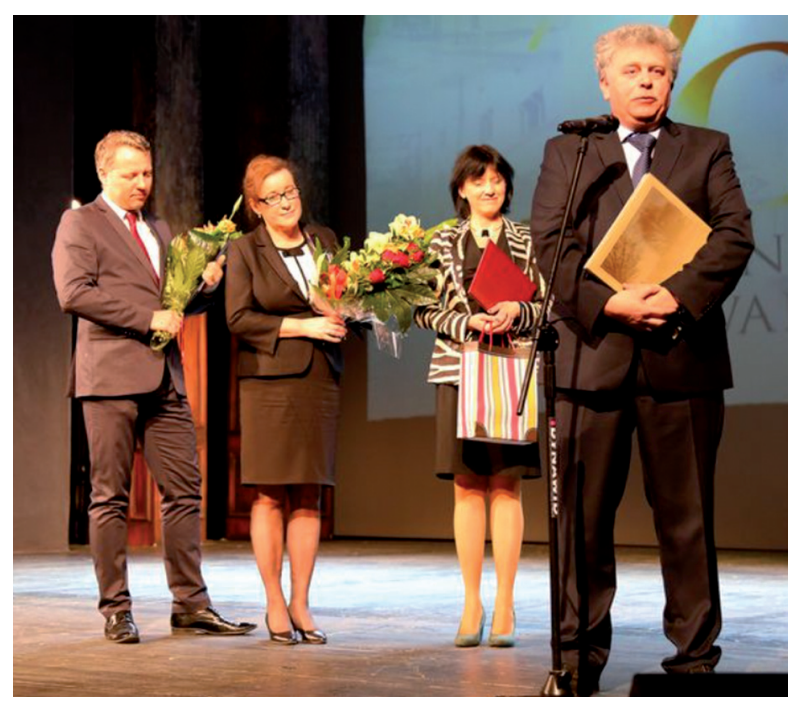
ników przeplatały się z losami zawodowymi i pracą naukową opisano w specjalnie wydanej na tę okoliczność Księdze Jubileuszowej, współtworzonej przez pracowników Instytutu pod redakcją prof. Jana Pilarczyka, dr. Bogusława Czwórnoga oraz prof. Eugeniusza Turyka.

Z okazji jubileuszu pracownicy Instytutu zostali odznaczeni Złotymi, Srebrnymi i Brązowymi Krzyżami Zasługi oraz Złotymi, Srebrnymi i Brązowymi Medalami za Długoletnią Służbę.

Instytut, jako pierwszy w Polsce, otrzymał Odznakę Honorową za Zasługi dla Rozwoju Gospodarki Rzeczypospolitej Polskiej, przyznaną przez Ministra Gospodarki Janusza Piechocińskiego. Niniejsze odznaczenie podkreśla niepodważalną rolę Instytutu Spawalnictwa w kształtowaniu przez 70 lat polskiego spawalnictwa i w wspieraniu polskiej gospodarki, zwłaszcza w sektorach wykorzystujących technologie i techniki spawalnicze.
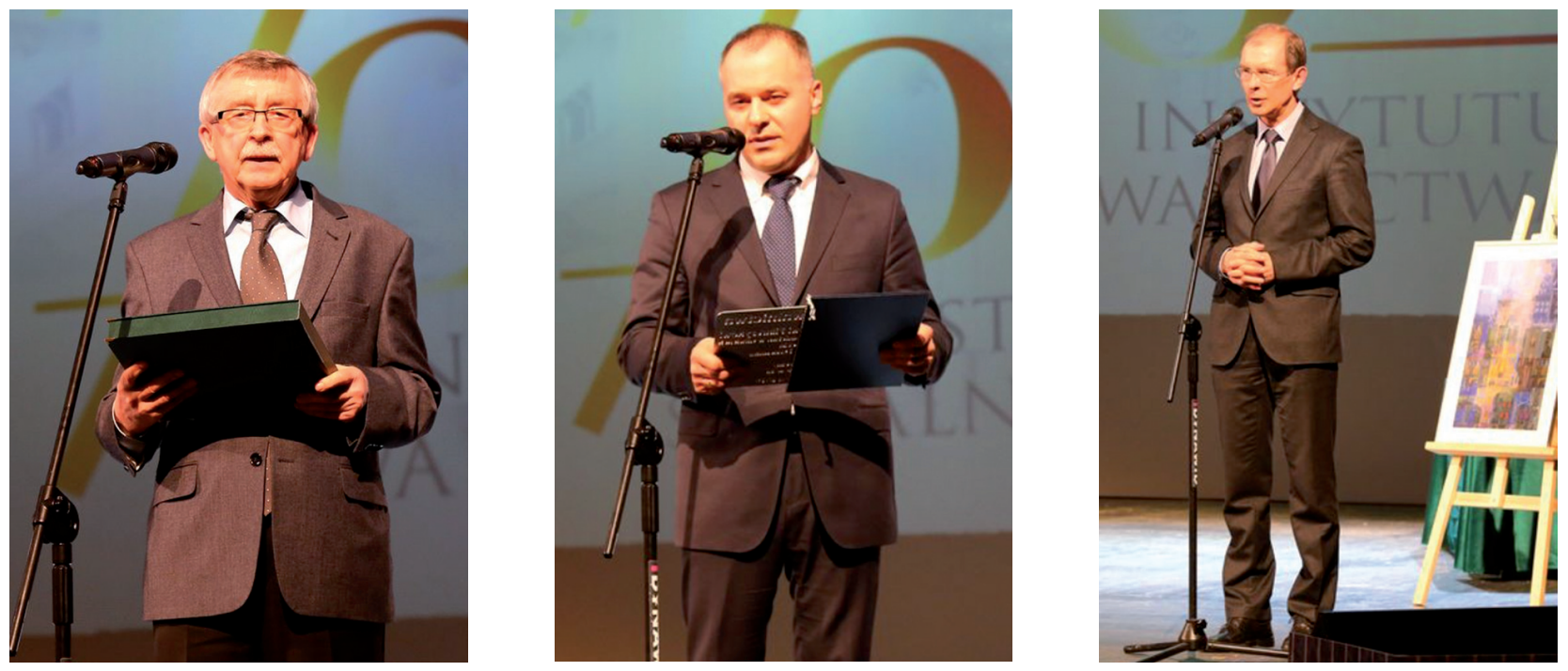

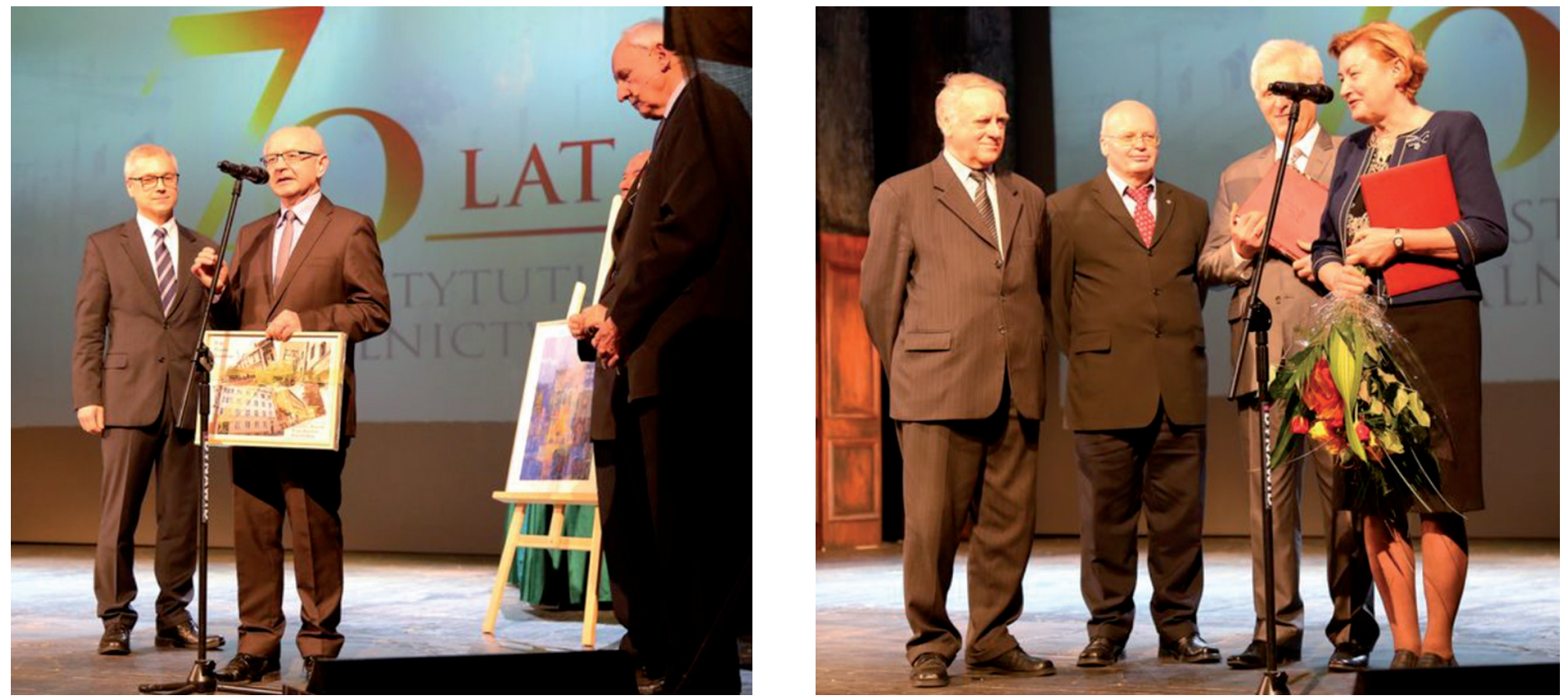

W drugiej części uroczystości głos zabrali licznie zaproszeni goście, gratulujący sukcesu oraz jubileuszu. Odczytano wiele adresów od osób i instytucji, często dziękując za współpracę. W wielu wygłoszonych przemówieniach podkreślano rolę i znaczenie Instytutu Spawalnictwa w rozwoju spawalnictwa i polskiej gospodarki.

Wiele ciepłych słów uznania skierowano bezpośrednio do wieloletniego dyrektora Instytutu i kreatora świętowanego sukcesu Prof. Jana Pilarczyka, kontynuatora wielkiego dzieła swojego ojca, współzałożyciela Instytutu Spawalnictwa w Gliwicach profesora Józefa Pilarczyka.
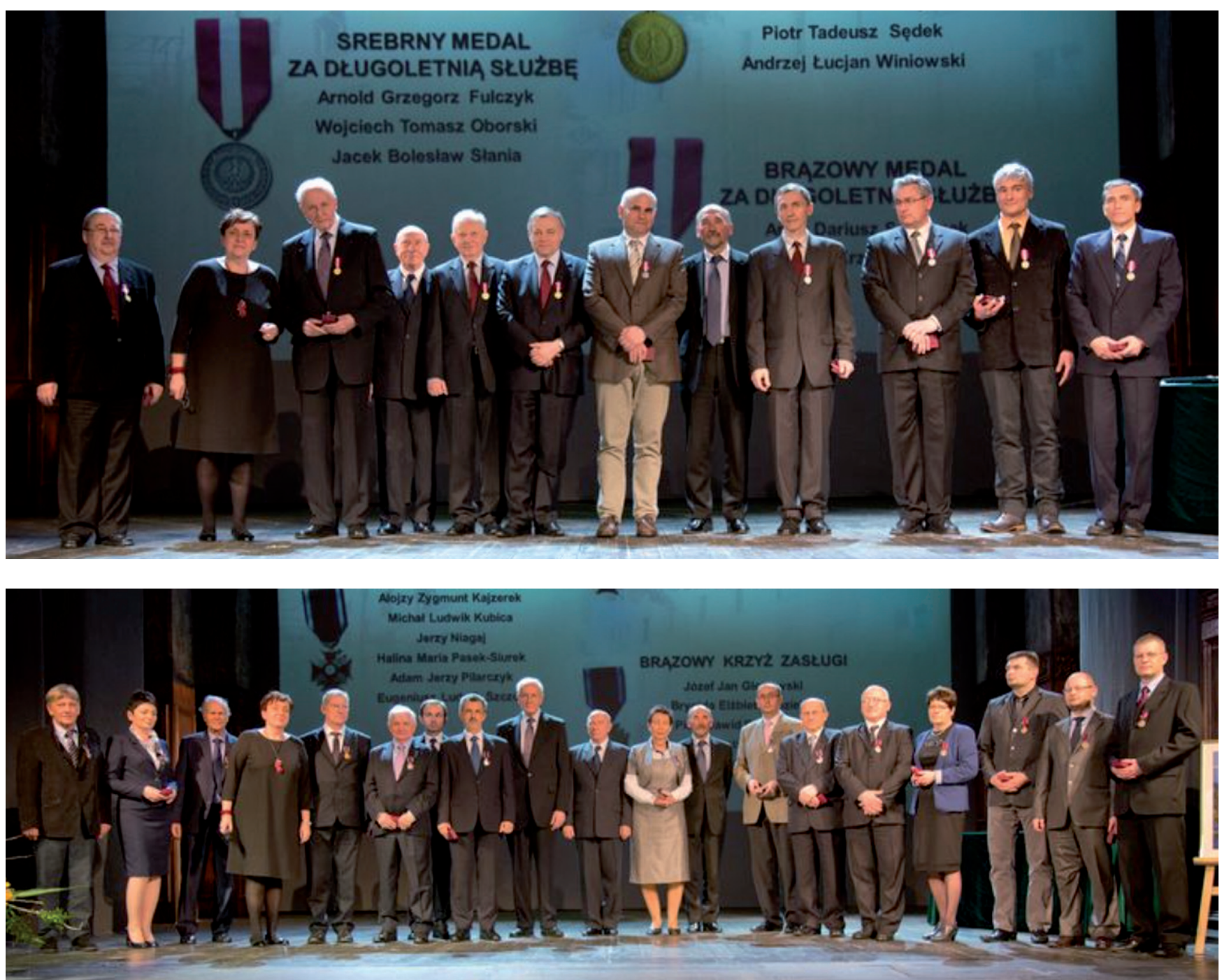

Uroczystość została zwieńczona i uświetniona koncertem pt. „Oskarowe przeboje muzyki filmowej” wykonanym przez artystów Teatru Muzycznego w Gliwicach. 


\section{Miller Electric}

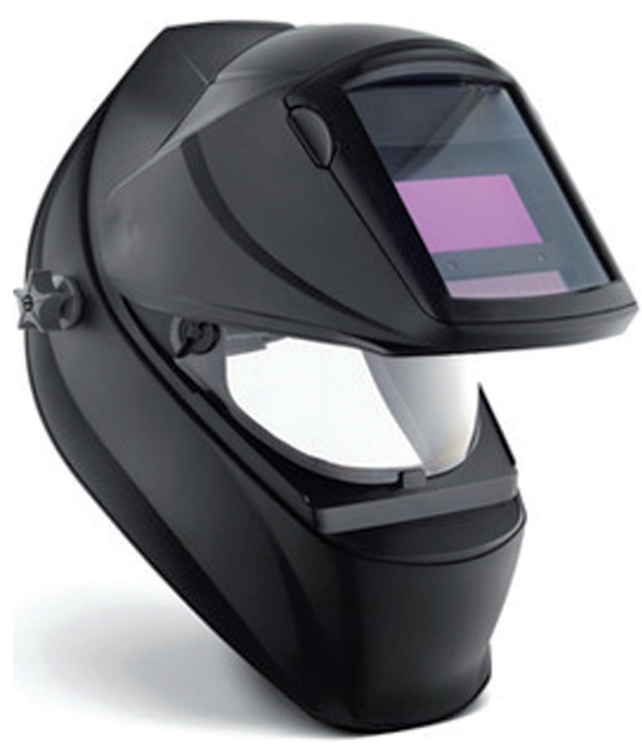

Firma Miller Electric oferuje dwa nowe modele samościemniających się przyłbic spawalniczych: Classic VSI oraz Classic FS \#10 2x4 flip-up. Oba rozwiązania powinny być interesujące dla użytkowników zarówno stosujących do tej pory filtry optyczne pasywne jak i dla użytkowników preferujących automatycznie ściemniające się filtry optyczne. Innowacyjność rozwiązania konstrukcyjnego polega na podnoszonej części z filtrem optycznym, która odsłania dużą wyprofilowaną szybę chroniącą twarz, jednocześnie umożliwiając szerokie pole widzenia podczas np. operacji szlifowania. Model VSI dysponuję zakresem stopnia zaciemnienia od 8 do 13 oraz dodatkowo wyposażony jest funkcję elektromagnetycznego rozpoznawania łuku spawalniczego eliminując fałszywe sygnały zewnętrzne, które mogłyby wywołać przypadkowe zaciemnienie filtra.

\section{www.millerwelds.com}

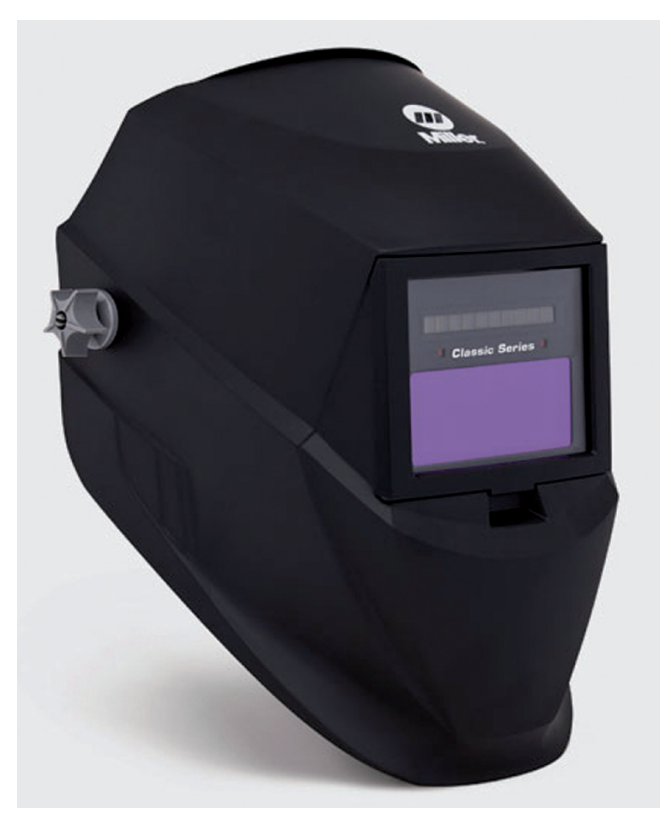

\section{Elektrody wolframowe}

Elektrody wolframowe z zielonymi oznaczeniami nie zawierają żadnych dodatków i służą głównie do spawania aluminium prądem przemiennym. dodatki tlenków: ceru, lantanu, cyrkonu i toru znacząco zwiększają trwałość termiczną elektrody oraz termoemisyjność. W tabeli poniżej przedstawiono przykłady oznaczania i zastosowanie wybranych elektrod zgodnie z EN ISO 6848

\section{Litty - www.tungsten.de}

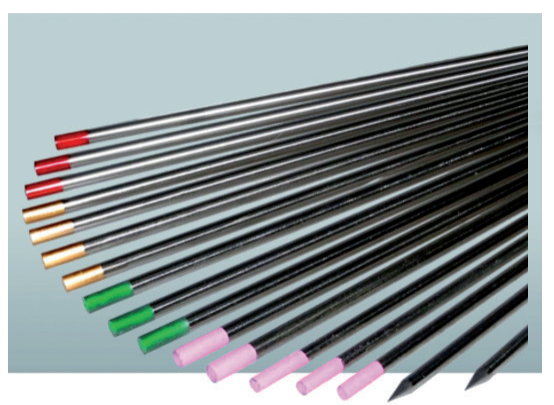

\begin{tabular}{|c|c|c|l|}
\hline Symbol & Dodatki [\% wag] & Kolor oznaczenia & \multicolumn{1}{|c|}{ Zastosowanie do spawania } \\
\hline WP & Bez dodatków & Zielony & Stopy aluminium AC z wysoką stabilnością łuku. \\
\hline WCe 20 & Tlenek ceru $-1,8 \div 2,3$ & Szary & $\begin{array}{l}\text { Stal, stopy: aluminium, tytanu, niklu, miedzi, } \\
\text { magnezu. }\end{array}$ \\
\hline WLa10 & Tlenek lantanu $-0,8 \div 2,2$ & Czarny & $\begin{array}{l}\text { Stal, stopy: aluminium, tytanu, niklu, miedzi, } \\
\text { magnezu. Ze względu na łatwe zajarzanie łuku } \\
\text { przeferowany } \\
\text { W spawaniu zautomatyzowanym. }\end{array}$ \\
\hline WZr8 & $\begin{array}{c}\text { Tlenek cyrkonu }- \\
0,7 \div 0,9\end{array}$ & Biały & $\begin{array}{l}\text { Spawanie AC z możliwością spawania DC } \\
\text { w ograniczonym zakresie. }\end{array}$ \\
\hline WTh10 & Tlenek toru $-0,8 \div 1,2$ & Żółty & $\begin{array}{l}\text { Spawanie DC, charakteryzuje się wysoką } \\
\text { trwałością. Tor jest lekko radioaktywny. }\end{array}$ \\
\hline
\end{tabular}




\section{Oprzyrządowanie montażowe - część 3}

Omówione w poprzedniej części urządzenia montażowe złożone, zarówno uniwersalne, jak i specjalne, wykorzystują elementy.

- ustalające położenie części składanej konstrukcji - tzw. ustalacze,

- mocujące (unieruchamiające) je w zadanym położeniu (zostaną omówione w kolejnej części).

Ustalenie (bazowanie) części polega na odebraniu jej pewnych stopni swobody poprzez zetknięcie baz stykowych z elementami ustalającymi tak, aby jej położenie było w pełni jednoznaczne. Baza (np. konstrukcyjna, technologiczna) ustalanej części to jej powierzchnia, linia lub punkt, względem których położenie rozpatrywanego innego punktu, linii lub powierzchni jest określone w sposób bezpośredni. W odniesieniu do konstrukcji spawanych, ustalenie dotyczy co najmniej dwóch części składowych, które po zakończonym procesie stają się monolitem. Każdej z ustalanych części można odebrać co najwyżej sześć stopni swobody, a elementem ustalającym (odbierającym stopnie swobody) może być również sąsiednia część spawanej konstrukcji. Mocowanie realizowane jest poprzez przyłożenie odpowiednio ukierunkowanej siły, wystarczającej do stabilnego unieruchomienia części w zadanym położeniu, np. dosuniętej do płaskiej powierzchni oporowej.

W celu nadania ustalonego położenia elementom składanej konstrukcji stosowane są tzw. ustalacze (rys. poniżej). Urządzenia zestawcze uniwersalne, oparte na modułowych stołach zaciskowych, bazują na komponentach prefabrykowanych. W urządzeniach specjalnych, tworzonych do składania i spawania (sczepiania) określonego wyrobu, ustalenie i mocowanie opiera się zarówno na elementach projektowanych i wykonywanych indywidualnie, jak i prefabrykowanych (np. niektóre pryzmy i kołki). Prawidłowe ustalenie powinno zapewnić wymaganą dokładność, sztywność i wytrzymałość bazowania, łatwy dostęp do miejsc spawania oraz możliwość swobodnego wyjęcia gotowego wyrobu z przyrządu.

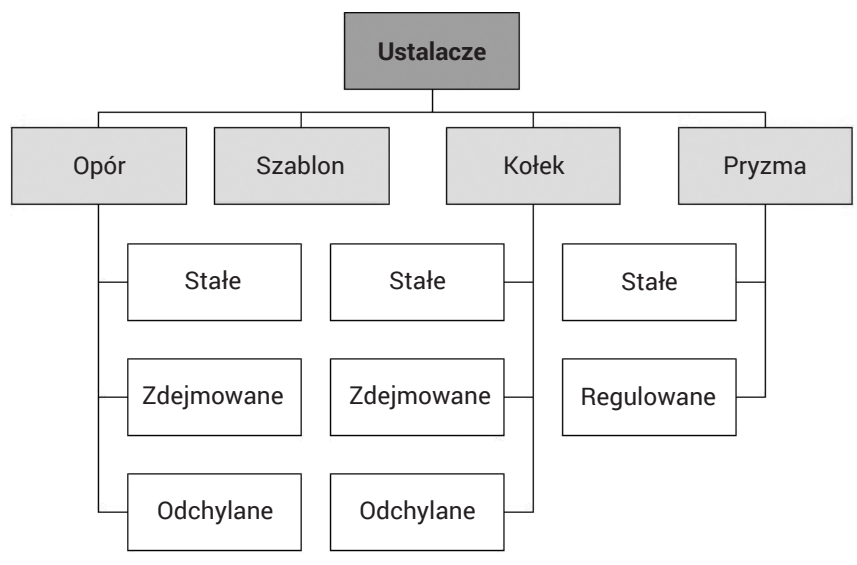

Opory o powierzchniach roboczych płaskich lub dostosowanych do kształtu ustalanej części mogą być stałe (trwale zamocowane do podstawy przyrządu), a także zdejmowane lub odchylane, stosowane jeśli opory stałe utrudniałyby wyjecie konstrukcji z przyrządu po spawaniu czy częściowo zasłaniały dostęp do spoin. W wariancie odchylanym zmniejsza się dodatkowo ryzyko zagubienia zdejmowanych części przyrządu. Z punktu widzenia sił działających wskutek ustalania i w następstwie nagrzewania oraz stygnięcia spawanych elementów, opory mogą być kierunkowe (nie przenoszące sił) oraz ograniczające (przenoszące siły). Z punktu widzenia liczby odbieranych stopni swobody konieczna jest analiza każdego przypadku. Przykładowo, płaska powierzchnia, na której położono płytkę, odbiera jej trzy stopnie. Dosunięcie bocznej krawędzi płaskiej płytki do długiej listwy odbiera jej dwa stopnie, a dosunięcie do oporu punktowego - jeden stopień. Na poniższym rysunku przedstawiono przykład urządzenia zestawczego specjalnego, w którym zastosowano regulowane opory działające punktowo, utworzone z blokowanych śrub (ZAP Robotyka).

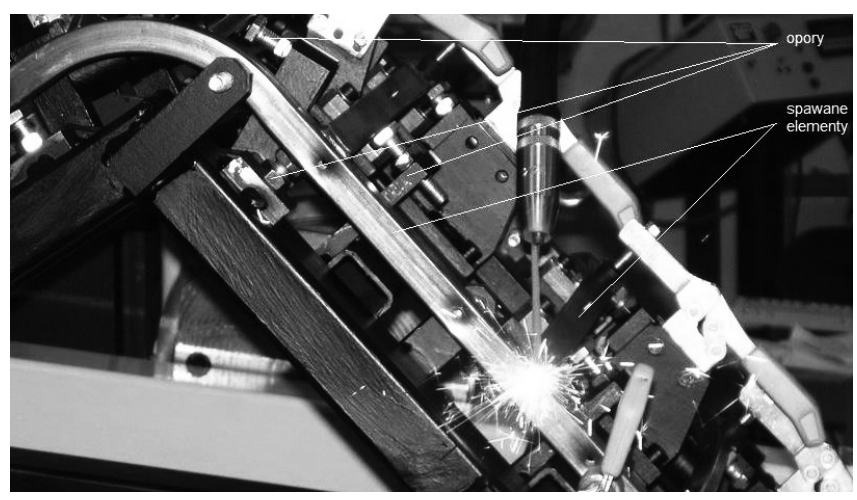

Szablon to prosty przyrząd pomocniczy do spawania, będący pierwowzorem wykonania jakiejś konstrukcji lub jej fragmentu. Może przyjąć postać nakładki na spawane elementy, wstępnie ustalającej ich położenie. Doraźnie, może nim być nawet wcześniej wykonana konstrukcja, np. przestrzenna rama, z przyspawanymi płytkami oporowymi pozwalającymi na identyczne złożenie i spawanie nowego wyrobu wprost na tak utworzonym szablonie.

Kołki i trzpienie ustalające stosowane się zwykle do bazowania części na otworach. Kołki mogą być stałe, trwale zamocowane do podstawy przyrządu, zdejmowane (np. mocowane na wcisk) lub odchylane. Ponadto, mogą być pełne i ścięte, zarówno bez, jak i z kołnierzem (rys. poniżej). Widać, że wariant $\mathrm{z}$ kołkiem wysokim umieszczonym wprost $\mathrm{w}$ podstawie przyrządu odbiera nadmierną liczbę stopni 
swobody (łącznie 7), przy niezablokowanym obrocie części wokół osi otworu bazującego. Pokazane obok, poprawne rozwiązania, wykorzystują kołek niski lub kołek wysoki z kołnierzem, separującym bazowaną część od podstawy przyrządu.

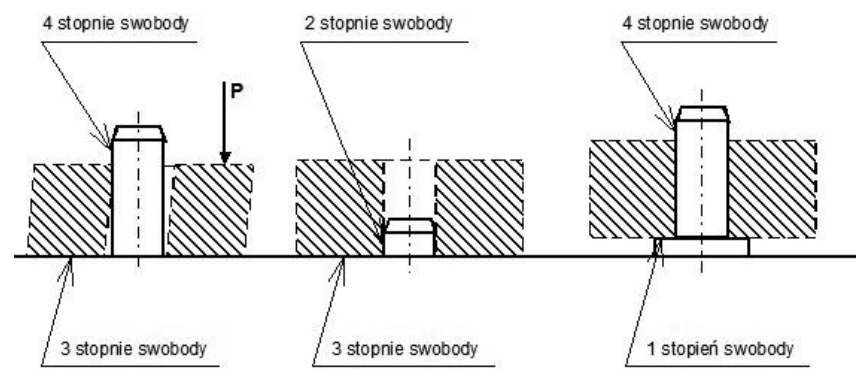

Elementy płaskie z otworami bazującymi, np. płytki, tłoczone blachy itp. można ustalić przy wykorzystaniu dwóch kołków, przy czym jeden zawsze jest pełny (cylindryczny), a drugi, w zależności od wariantu, może być ścięty (odbierając jeden stopień swobody, oznaczony 1 na rys. poniżej) lub pełny, ale umieszczony na zewnątrz, pełniący tu rolę oporu stałego (oznaczony 2 na rys. poniżej). Użycie większej liczby kołków nie jest zalecane z uwagi na ryzyko niezłożenia części w przyrządzanie (niedokładności wymiarowe) lub wyjęcia po spawaniu (naprężenia i odkształcenia po spawaniu).

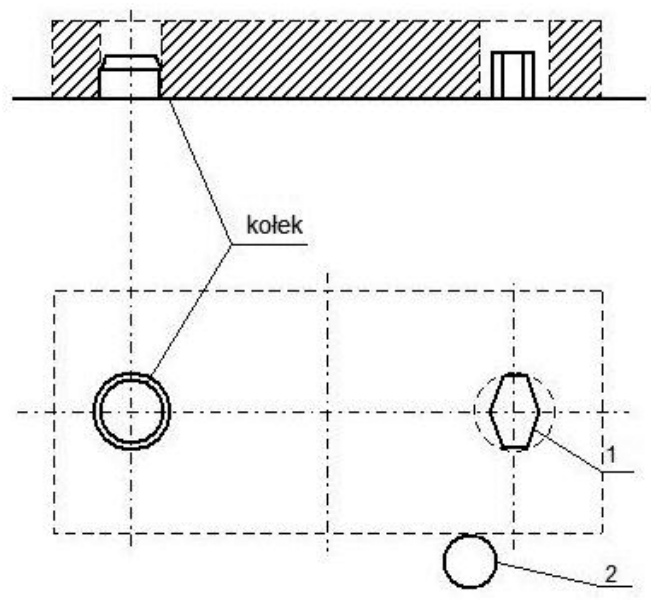

Pryzma, utworzona przez dwie ściany oporowe ustawione pod kątem (najczęściej 90²), może być stała lub regulowana. Wykorzystywane są przede wszystkim do ustalania położenia elementów walcowych (a także rur o innych przekrojach, np. prostokątnych). Pryzma odbiera części walcowej cztery stopnie swobody - niezablokowane pozostaje przesunięcie oraz obrót wokół własnej osi. Przy ustalaniu położenia długich, także wygiętych rur będących np. częścią złożonych ram, mogą być stosowane pryzmy w postaci płaskich, wyciętych z blachy segmentów.

$\mathrm{Na}$ fotografii pokazano fragment urządzenia zestawczego wykorzystującego kołki w roli punktowych oporów stałych, pryzmy (o kacie rozwarcia $90^{\circ}$ ) oraz liczne opory stałe dopasowane do rozmiaru i położenia ustalanych części. Elementy bazujące pokryto miedzią, zapobiegającą przywieraniu rozprysku spawalniczego (ZAP Robotyka).

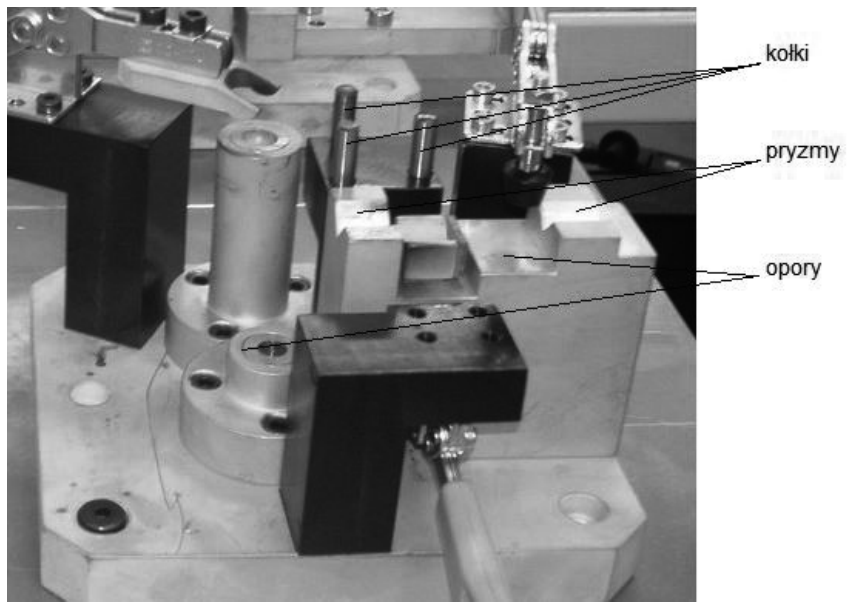

W przypadku urządzeń montażowych mających spełniać wysokie wymagania wymiarowe, w tym zbudowanych z materiałów o podwyższonej wytrzymałości i odporności na ścieranie, ustalacze powinny być łączone z podstawą (ramą) przyrządu przez ich wkręcenie (kołki, trzpienie), wciśnięcie, za pośrednictwem śrub itp. W szczególnych przypadkach końcowa kalibracja położenia elementów ustalających, poprzedzająca ich ostateczne zablokowanie (np. kołkami), prowadzona jest przy wykorzystaniu współrzędnościowych maszyn pomiarowych. Jedynie przyrządy budowane doraźnie lub przeznaczone do składania i spawania najmniej odpowiedzialnych (dokładnych) konstrukcji mogą być częściowo, a nawet w całości, zmontowane przez spawanie. 


\subsubsection{5 r. Stalowa Wola}

II Podkarpackie Seminarium Spawalnicze, Informacje i zgłoszenia: Marta Pracoń,

tel. 1264393 20, marta.pracon@pl.linde-gas.com

\subsubsection{5 r. Olsztyn}

Warmińsko-Mazurskie Spotkanie Spawalników, Informacje i zgłoszenia: Mirosława Reschke, miroslawa.reschke@pl.linde-gas.com

\subsubsection{5 r. Wrocław}

IV Dolnośląskie Sympozjum Spawalnicze, Informacje i zgłoszenia: dr Artur Lange, tel. 7132021 45, artur.lange@pwr.wroc.pl

09-12.06.2015 Poznań

ITM Polska, Innowacje Technologie Maszyny, Machtool Organizator: Międzynarodowe Targi Poznańskie

\subsubsection{5 r. Gdańsk}

XIX Pomorskie Spotkanie Spawalników, Informacje i zgłoszenia: Iwona Janson, tel. 5851128 00, iwona.janson@pl.linde-gas.com

\subsubsection{5 r. Szczecin}

XIV Szczecińskie Seminarium Spawalnicze, Informacje i zgłoszenia: Katarzyna Rudzka, tel. 9146242 75, katarzyna.rudzka@pl.linde-gas.com

\subsubsection{5 r. Poznań}

II Wielkopolskie Seminarium Spawalnicze, Informacje i zgłoszenia: Wioletta Buchta, tel. 6162582 50, wioletta.buchta@pl.linde-gas.com

\section{Listopad 2015 r. Warszawa}

I Ogólnopolska Konferencja Naukowo-Techniczna pod hasłem: „Problemy inżynierii bezpieczeństwa obiektów antropogenicznych"

Organizatorzy: SIMP Oddział Warszawski, Centrum Rzeczoznawstwa Budowlanego

\section{6-28.05.2015 r. Międzyzdroje
XXI Naukowo-Techniczna Krajowa Konferencja Spawalnicza
Postęp, innowacje i wymagania jakościowe procesów spajania
Organizatorzy:
Zachodniopomorska Sekcja Spawalnicza Stowarzyszenia Inżynierów Mechaników i Techników Polskich,
Polskie Towarzystwo Badań Nieniszczących i Diagnostyki Technicznej - SIMP O/Szczecin,
Urząd Dozoru Technicznego, Biuro Techniki Spawalniczej „BM”}

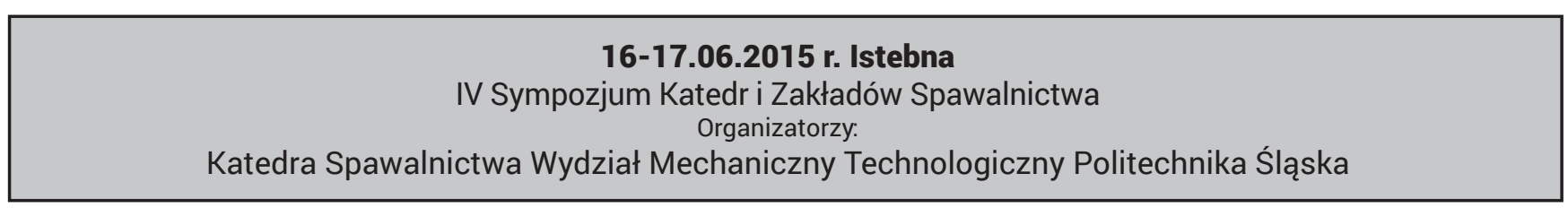

\begin{tabular}{c} 
22-24.09.2015 r. Wrocław \\
4. Międzynarodowa Konferencja Naukowa \\
Natryskiwania Cieplnego i Napawania \\
Postęp, zastosowania i nowoczesne technologie \\
Organizatorzy. \\
Wydział Mechaniczny Politechniki Wrocławskiej, Katedra Materiałoznawstwa, Wytrzymałości i Spawalnictwa; \\
Zarząd Główny Stowarzyszenia Inżynierów Mechaników i Techników Polskich; \\
Politechnika Świętokrzyska; Centrum Laserowych Technologii Metali Politechniki Śląskiej i PAN \\
\hline
\end{tabular}
19-21.10.2015 r. Jachranka / pod Warszawą
57. Krajowa Konferencja Spawalnicza
Innowacje w inżynierii spajania Organizatorzy:
Zakład Inżynierii Spajania Politechnika Warszawska, Sekcja Spawalnicza SIMP,
Przegląd Spawalnictwa
informacje: www.zis.pw.edu.pl/konferencja 


\section{Profil czasopisma}

Wydanie czasopisma jest wspierane finansowo przez Ministerstwo Nauki i Szkolnictwa Wyższego.

Odbiorcami Przeglądu Spawalnictwa, czasopisma o ponad osiemdziesięcioletniej tradycji, są wszystkie ośrodki naukowe, dydaktyczne i organizacje przemysłowe w Polsce zainteresowane problematyką spajania. Czasopismo jest wysyłane do ważnych ośrodków zagranicznych zainteresowanych tą tematyką. W czasopiśmie Przegląd Spawalnictwa są publikowane recenzowane, oryginalne artykuły dotyczące: techniki spajania, cięcia, powłok spawalniczych; metalurgii, metaloznawstwa i modelowania procesów spawalniczych; metod badań struktury i właściwości złączy; charakterystyki urządzeń, sprzętu i materiałów; automatyzacji i robotyzacji; technik klejenia tworzyw konstrukcyjnych i spawania tworzyw polimerowych; szkoleń, przepisów i normalizacji; praktyki spawalniczej i poradnictwa technologicznego; wydarzeń, prezentacji karier spawalników i ich doświadczeń zawodowych. Wybrane artykuły opublikowane w Przeglądzie Spawalnictwa są tłumaczone na język angielski i zamieszczane w czasopiśmie Welding International wydawanym przez Woodhead Publishing Ltd. w Wielkiej Brytanii na mocy porozumienia o współpracy. W czasopiśmie mogą być publikowane artykuły w języku angielskim lub niemieckim.

Redakcja nie odpowiada za treść ogłoszeń, nie zwraca materiałów nie zamówionych, zastrzega sobie prawo do skracania i adiustacji tekstów oraz zmiany ich tytułów. Czasopismo wydawane w wersji drukowanej.

\section{Wskazówki dla autorów}

Objętość artykułu maksymalnie 7 stron (9 po uzgodnieniu z redakcją), a komunikatu $1 \div 4$ stron maszynopisu na arkuszu formatu A4 bez tabulatorów i wcięć, czcionka Times New Roman 12, marginesy: górny, dolny, lewy i prawy - 2,5 cm, odstęp między wierszami 2. Rysunki i tablice z ich tytułami należy umieścić w tekście. Rysunki, wykresy i fotografie należy nazywać rysunkami (np. rys. 1) i numerować cyframi arabskimi, a tablice - cyframi rzymskimi (np. tabl. IV). Należy przewidzieć możliwość zmniejszenia rysunku do $30 \%$. Rysunki dostarczyć w oddzielnych plikach przed ich importem do Word: rastrowa w formacie *.TIFF, *.JPEG 300 DPI; wektorowa w plikach *.CDR, *.Al (czcionka zamieniona na krzywe). Jednostki - układ SI. Wzory matematyczne należy przygotować w edytorze wzorów Word (Math Type). Artykuł powinien zawierać: informacje o autorach - stopnie naukowe lub zawodowe, imię i nazwisko; tytuł artykułu, streszczenie (do $1 \frac{1}{3}$-strony), tekst główny, podzielony na odpowiednio zatytułowane rozdziały, wnioski końcowe, literaturę (sposób zapisu literatury: [1] J. Nowak, J. Kowalski, „Tytuł artykułu” Przegląd Spawalnictwa, vol.87 (1), s. 58-64, 2015.); pozycje literatury numerowane cyframi arabskimi w kwadratowych nawiasach i w kolejności cytowania w tekście. Tytuł, streszczenie, słowa kluczowe (maks. 3) oraz podpisy pod rysunkami i tabelami przetłumaczone na język angielski. Artykuły prosimy nadsyłać na CD lub e-mailem z pismem przewodnim zawierającym: zgodę na publikację artykułu w czasopiśmie; dane teleadresowe i miejsce pracy autorów do wiadomości redakcji. Zespół autorów otrzymuje bezpłatnie plik pdf swojej publikacji.

\section{Ogłoszenia i artykuły promocyjne}

Ogłoszenia i artykuły promocyjne w Przeglądzie Spawalnictwa - czasopiśmie ogólnopolskim o szerokim zasięgu - są skuteczną i tanią formą reklamy docierającej do wszystkich zainteresowanych problematyką spajania. Czasopismo zamieszcza kolorowe i czarno-białe: ogłoszenia reklamowe na okładkach lub wewnątrz numeru oraz wrzutki (inserts) dostarczane przez zleceniodawcę; artykuły technicznoinformacyjne; informacje o branżowych imprezach naukowo-technicznych. Redakcja przyjmuje zamówienia na publikacje ogłoszeń reklamowych i artykułów techniczno-informacyjnych. Cennik ogłoszeń i artykułów promocyjnych znajduje się na stronie www.pspaw.pl

\section{PREN U MERAT A}

\section{Cena: \\ 1 egzemplarz Przeglądu Spawalnictwa} W prenumeracie $17 \mathrm{zł}$ (w tym 5\% VAT)

1 egzemplarz poza prenumeratą (również numery archiwalne - jeśli dostępne) 25 zł (w tym 5\% VAT)

W celu zamówienia prenumeraty w Redakcji należy wypełnić formularz i przesłać go na adres: redakcja@pspaw.pl

ZG SIMP - Redakcja Przegląd Spawalnictwa
Agenda Wydawnicza
ul. Świętokrzyska 14
00-050 Warszawa
tel.: 228272542

Zamawiam czasopismo Przegląd Spawalnictwa

$\begin{array}{lr}\text { półroczna } & 102 \mathrm{zf} \\ \text { roczna } & 204 \mathrm{zf} \\ \text { od numeru } & \text { do numeru }\end{array}$

liczba zamawianych kompletów

Imię i nazwisko:

Firma:

Adres:

NIP:

@mail osoby zamawiającej:

Oświadczam, że jestem podatnikiem VAT i upoważniam firmę do wystawienia faktury bez podpisu 
Zakład Inżynierii Spajania Politechniki Warszawskiej

Sekcja Spawalnicza SIMP oraz Przegląd Spawalnictwa

\section{w 57. Naukowo-Technicznej Konferencji Spawalniczej}

\section{pod hasłem \\ Innowacje w inżynierii spajania}

która odbędzie się w dniach

19-21 października $2015 \mathrm{r}$.

Tematyka konferencji obejmuje wszystkie zagadnienia naukowo-techniczne

z szeroko pojętej inżynierii spajania.

Patronat Honorowy

JM Rektor Politechniki Warszawskiej Prezes Urzędu Dozoru Technicznego prof. dr hab. inż. Jan Szmidt Mieczysław Borowski

Konferencja odbędzie się na terenie

Windsor Palace Hotel ${ }^{* \star * *}$ w Jachrance

oddalonej od centrum Warszawy o ok. $40 \mathrm{~km}$

www.windsorhotel.pl

Szczegółowe informacje na stronie internetowej:

www.zis.wip.pw.edu.pl/konferencja

Kontakt do Organizatorów:

tel./fax: +48 2284996 21; +48222348402

Sponsor Generalny konferencji

Właściciel marki
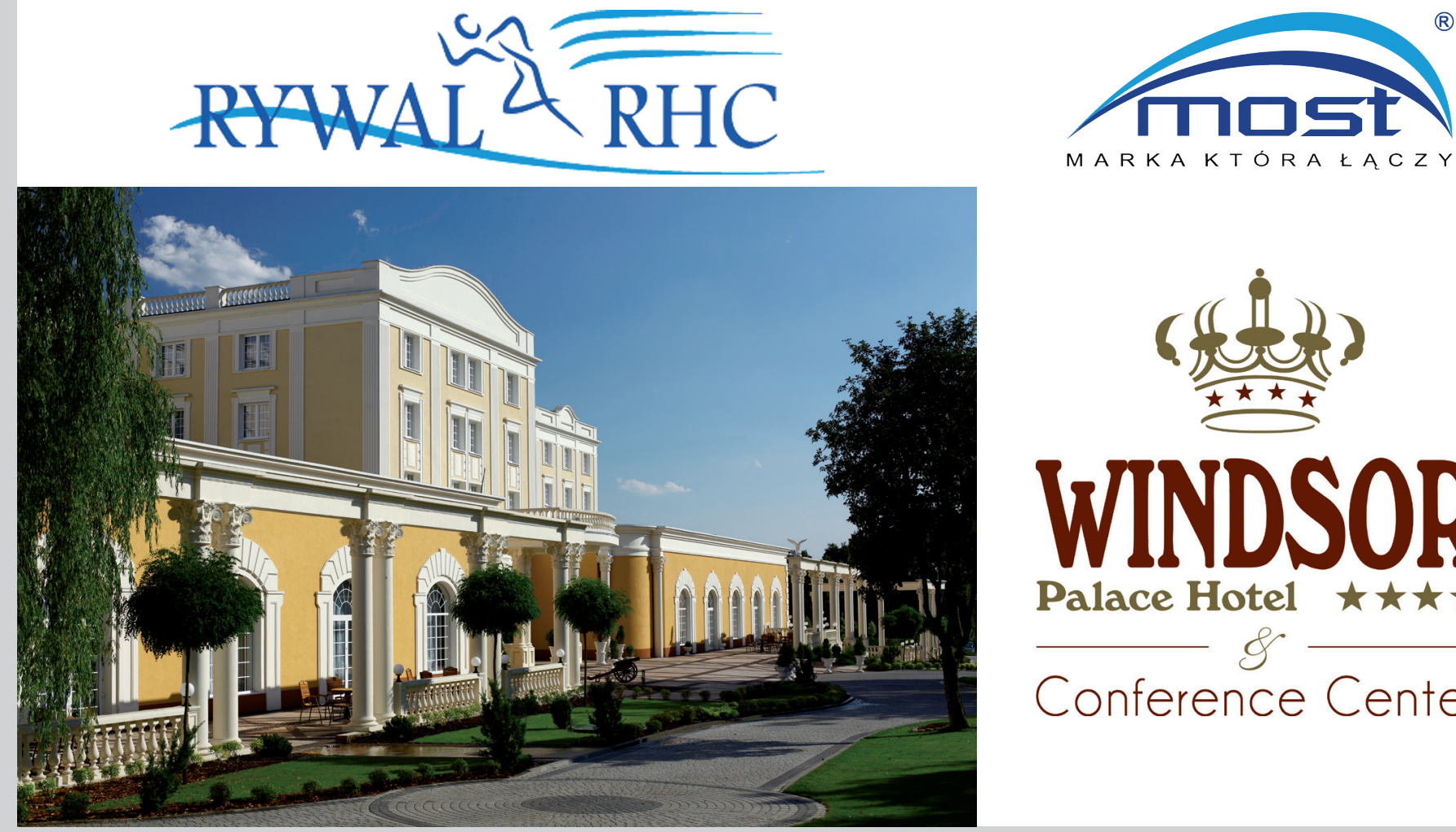

MARKAKTÓRA

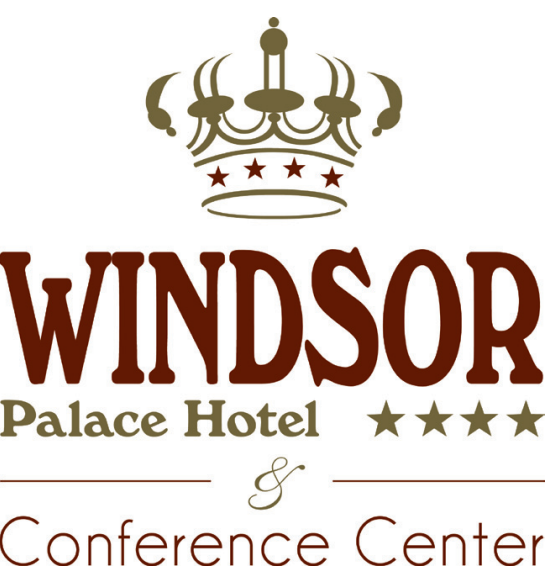




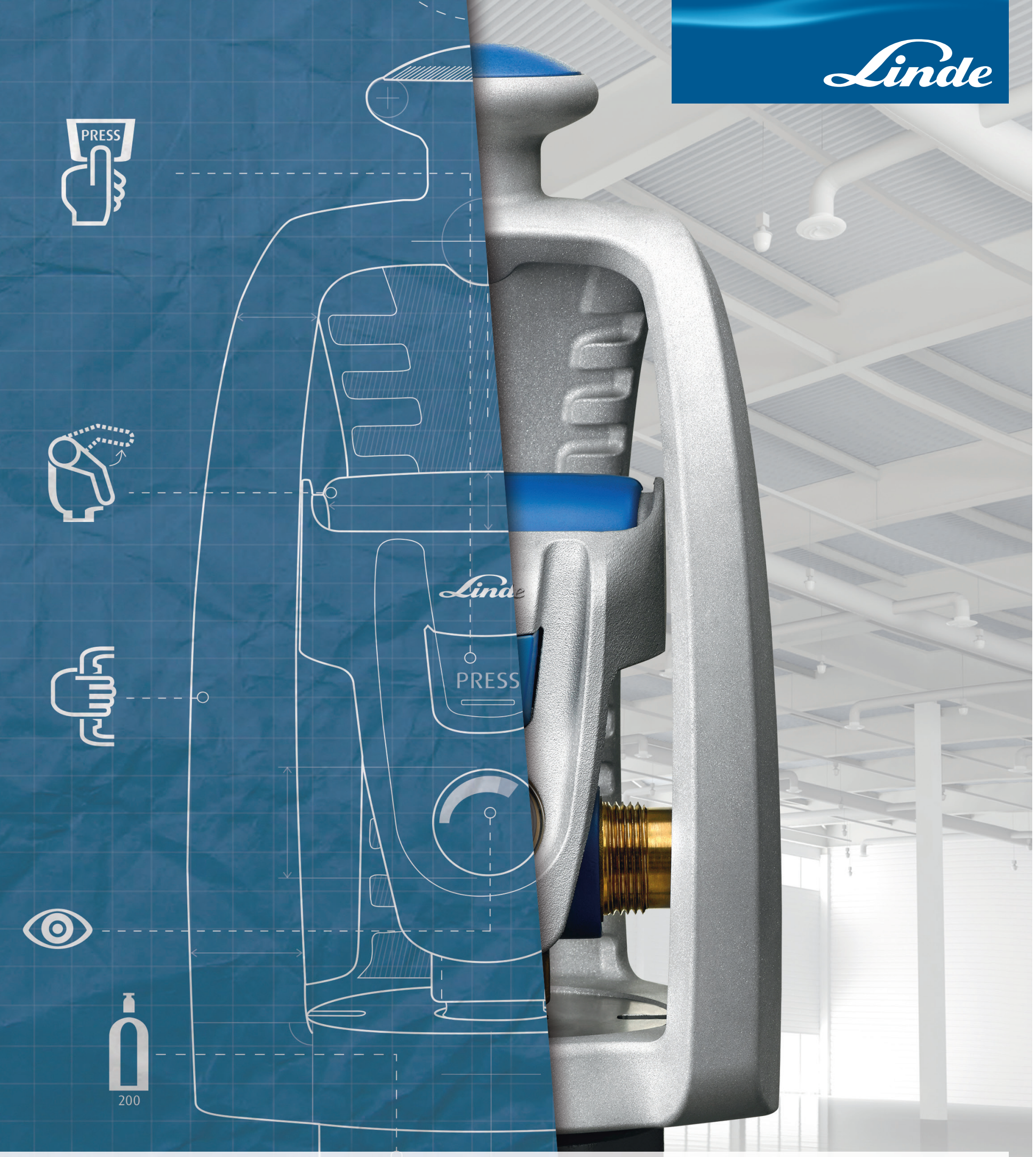

\section{Przedstawiamy EVOS ${ }^{T M}$}

Innowacyjny i ergonomiczny. Bezpieczny i prosty w użyciu.

EVOS Ci - pierwszy zawór butlowy dźwigniowy z linii EVOS ${ }^{T M}$ z wbudowanym wskaźnikiem ilości gazu przystosowany do pracy przy bardzo wysokim ciśnieniu. Wyposażony jest w łatwo dostępną dźwignię otwarcia/zamknięcia oraz osłonę zabezpieczającą spełniającą równocześnie funkcję wygodnego uchwytu.

EVOS $^{T M}$ wyznacza nowe standardy wydajności, bezpieczeństwa i komfortu pracy. 